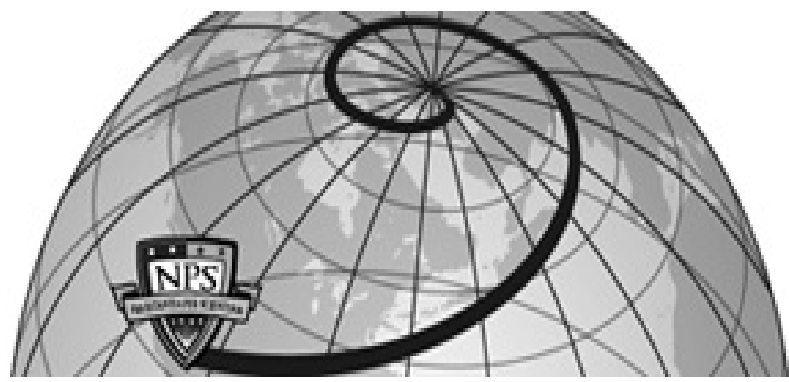

Calhoun: The NPS Institutional Archive DSpace Repository

1979-03

\title{
Winter and spring oceanographic conditions in and under the ice of the Bering Sea
}

Lohrmann, Walter Richard

Monterey, California. Naval Postgraduate School

http://hdl.handle.net/10945/27336

This publication is a work of the U.S. Government as defined in Title 17, United States Code, Section 101. Copyright protection is not available for this work in the United States.

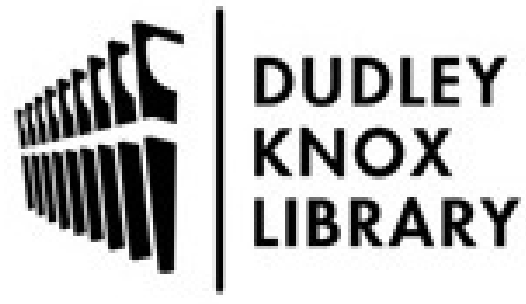

http://www.nps.edu/library
Calhoun is the Naval Postgraduate School's public access digital repository for research materials and institutional publications created by the NPS community. Calhoun is named for Professor of Mathematics Guy K. Calhoun, NPS's first appointed -- and published -- scholarly author.

Dudley Knox Library / Naval Postgraduate School 411 Dyer Road / 1 University Circle Monterey, California USA 93943 


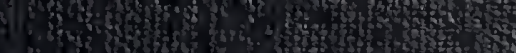

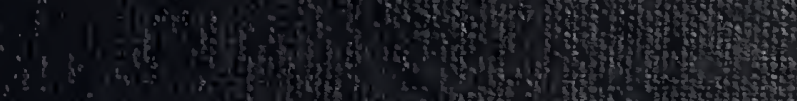

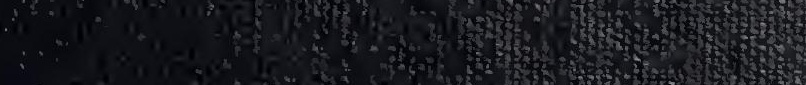

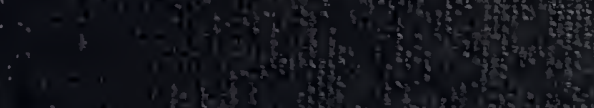

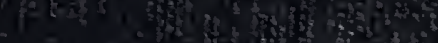

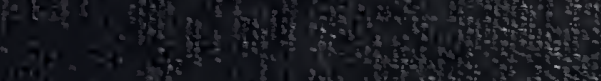

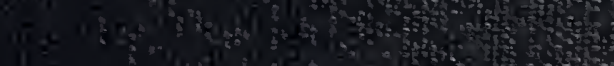

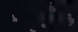

$-x^{\infty}+x^{2}$

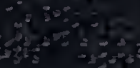

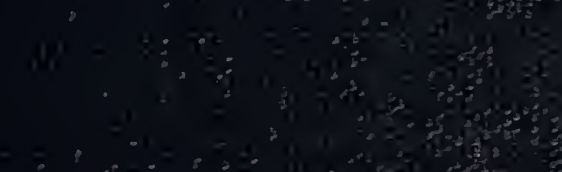

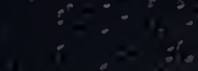
$\therefore: 3$

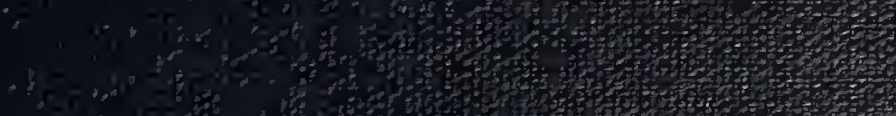

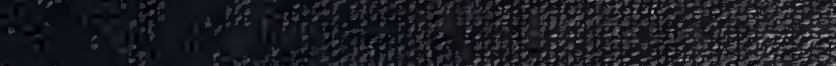
ath $x^{2}=13$

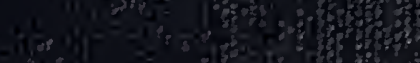
H. if

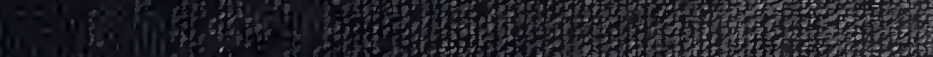

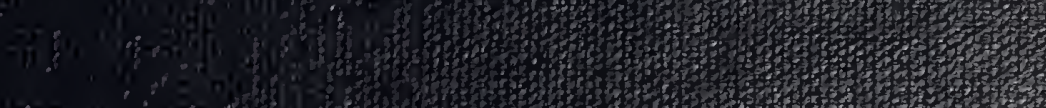

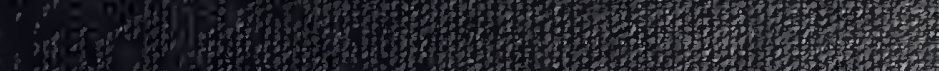

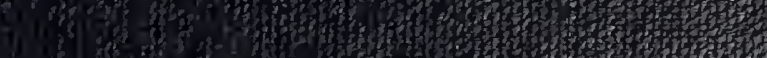




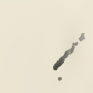


NPS 68-79-001

\section{NAVAL POSTGRADUATE SCHOOL Monterey, California}

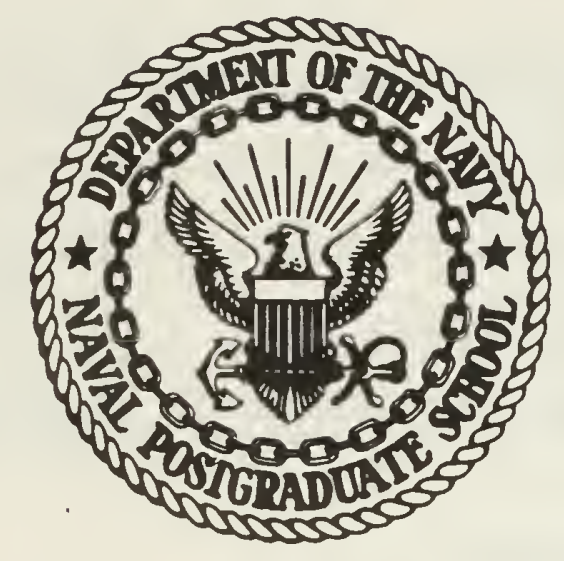

\section{THESIS}

WINTER AND SPRING OCEANOGRAPHIC CONDITIONS IN AND UNDER THE ICE OF THE BERING SEA

by

Walter Richard Lohrmann March 1979

Thesis Advisors:

R. G. Paquette

R. H. Bourke

Approved for public release; distribution unlimited.

A report submitted to:

Director, Arctic Submarine Laboratory

Naval Ocean Systems Center, San Diego 


\section{NAVAL POSTGRADUATE SCHOOL Monterey, California}

Rear Admiral T. F. Dedman Superintendent

Jack R. Borsting Provost

This thesis is prepared in conjunction with research supported in part by the Arctic Submarine Laboratory, Naval Ocean Systems Center, San Diego, California under Project Order Nos. 00002 and 00004 .

Reproduction of all or part of this report is authorized. 


\section{REPORT DOCUMENTATION PAGE}

READ INSTRUCTIONS

BEFORE COMPLETING FORM

1. RETORT NUMUTh

NPS 68-79-001

OOVT ACCESBION NO.

3. RECIPIENT'S CATALOG NUMEEA

DN 89440

4. TITLE (and Subirlle)

3. TYPE OF REPORT A PEAIOD COVERED

Interim - 14 July 1978

Winter and Spring Oceanographic Conditions 12 April 1979

In and Under the Ice of the Bering sea

\section{AUTHOR(•)}

- penfonming ong. neport numeer NPS 68-79-001

Walter $\mathrm{R}$. Lohrmann in conjunction with

Robert G. Paquette and Robert H. Bourke

\section{PEAFonMINo OROANIZATION NAME AND ADDRESB}

Naval Postgraduate School

Monterey, California 93940

D. CONTRACT OR GRANT NUMEER(ด)

N66001-78-PO-00002 N66001-79-PO-00004

10. PAOGAAMELEMENT, PROJECT, TASK

Element : $62759 \mathrm{~N}$; Work:

MRO1549A09; Project: ZF52

555; Task: ZF52-555-001

1. CONTAOLLING OFFICE NAME AND ADDAESS

Arctic Submarine Laboratory

Code 54, Bldg. 371, Naval Ocean SystemsCnt

San Diego, California 92152

12. AEPOAT DATE

March 1979

14. MONITONING AGENCY NAME ADDRESS(II dIllormi from Controllind Offleo)

65 pages

18. SECURITY CLASS. (ol inte roport)

unclassified TS. DECLABSIFICATION/OOWNGRADING

\section{DISTRIOUTION STATEMENT (ol thle Report)}

Approved for public release; distribution unlimited.

17. OISTRIDUTION STATEMENT (ol the ebefrect entered in Dlook 20, II difforent from Report)

18. SUPPLEMENTARY NOTES

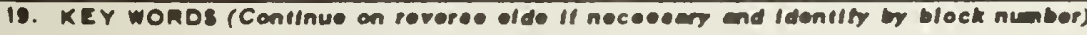

Marginal sea-ice zone, MIZPAC, thermal finestructure, oceanography Bering Sea, Chukchi Sea, fronts.

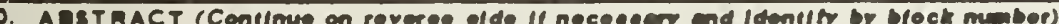

A search for thermal fronts and presumed associated finestructure near the ice of the Bering sea was carried out using historical oceanographic data. A few weak fronts were found during the months of February to May. Strong fronts and, probably, finestructure existed in the northern Bering sea in June. Some conclusions were drawn about the winter brine convection process.

DD, IOAM 1473

(Page 1)
EDITION OF I NOV ES IS ODSOLETE $S / N 0102 \cdot 014 \cdot 66011$ unclassified SECUAITY CLABSIFICATION OF TMIS PAOE (WTME DaCE Incered) 

Approved for public release; distribution unlimited.

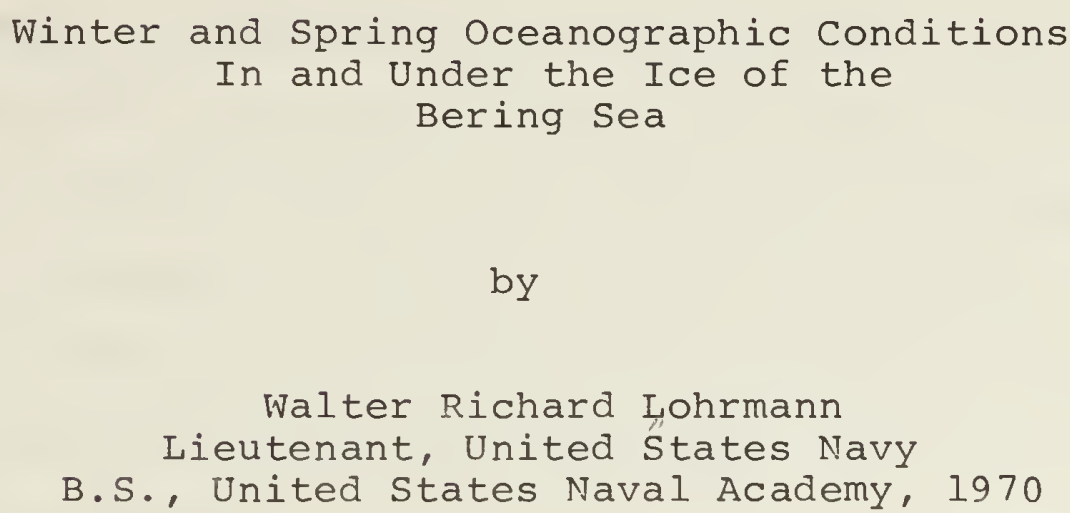

Submitted in partial fulfillment of the requirements for the degree of

MASTER OF SCIENCE IN OCEANOGRAPHY

from the

NAVAL POSTGRADUATE SCHOOL March 1979 



\section{ABSTRACT}

A search for thermal fronts and presumed associated finestructure near the ice of the Bering sea was carried out using historical oceanographic data. A few weak fronts were found during the months of February to May. Strong fronts and, probably, finestructure existed in the northern Bering sea in June. Some conclusions were drawn about the winter brine convection process. 



\section{TABLE OF CONTENTS}

I.

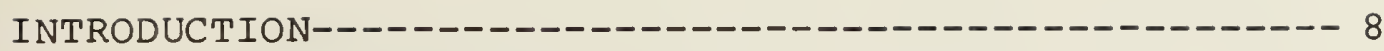

A. BACKGROUND------

B. OBJECTIVES-------------

C. FINESTRUCTURE AND TEMPERATURE FRONTS IN THE

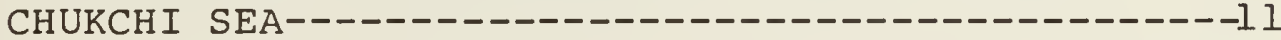

D. GENERAL OCEANOGRAPHY OF THE BERING SEA----------13

1. Topography of the Bering Sea----------------13

2. Ice Distribution and Behavior--------------15

3. Currents and Water Masses-----------------16

II. PROCEDURES---------

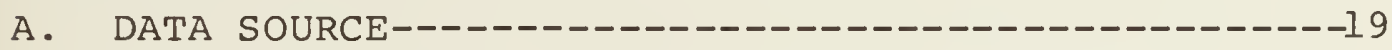

B. DATA REDUCTION----_-

C. DATA LIMITATIONS-----------------------------21

D. DATA ANALYSIS AND DISPLAY---------------------23

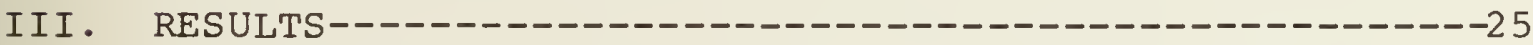

A. TEMPERATURE FRONTS----

B. UNDER-ICE PROCESSES AND WIND MIXING------------29

C. BOTTOM WATER OBSERVATIONS----------------------3I

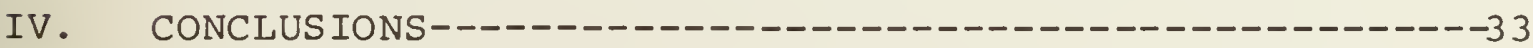

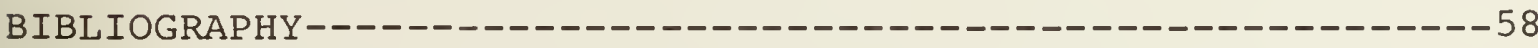

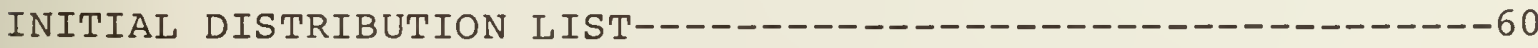





\section{LIST OF TABLES}

TABLE I. Summary of Oceanographic Cruises from Which Data

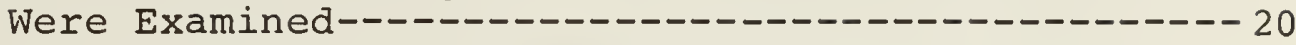

TABLE II. Contour Intervals and Limits Used in Plotting---- 24 



\section{LIST OF FIGURES}

1. Bathymetry and geographic locations in the Bering Sea--34

2. Temperature and density cross-section F25--------------35

3. Winter circulation in the Bering Sea--------------- 36

4. February oceanographic station positions---------------37

5. March oceanographic station positions----------------- 38

6. April oceanographic station positions----------------- 39

7. May oceanographic station positions---

8. June oceanographic station positions-------------------41

9. Oceanographic stations of primary interest - February--42

10. Oceanographic stations of primary interest - March-----43

11. Oceanographic stations of primary interest - April-----44

12. Temperature front distribution and location of warm water observations-------------------------------45

13. Temperature and salinity cross-section F25 (stations 3,4, and 5) ---------------------------46

14. Temperature cross-section MI---

15. Temperature cross-section F2---

16. Temperature cross-section A9---- ---------------49

17. Temperature and salinity cross-section MAl6-----------50

18. Temperature cross-section Jl------------------------- 51

19. Temperature cross-section J2---- ---------------52

20. Density cross-section F2----------------------------- 53

21. Density cross-section M7----------------------- 54

22. Density cross-section Al6--------------------------- 55

23. Density cross-section MAl6-----

24. Salinity cross-section F6--------------------------- 57 



\section{ACKNOWLEDGEMENT}

I wish to express my gratitude to the faculty and staff of the Naval Postgraduate School for their help and guidance throughout my graduate studies. A special note of gratitude is due Drs. R. G. Paquette and R. H. Bourke for their continuous interest and patience during the preparation of this thesis. I would like to also thank the "night crew" of the W. R. Church Computer Center for the assistance and responsiveness so willingly provided in the production of large numbers of computer products. 



\section{INTRODUCTION}

\section{A. BACKGROUND}

Severe temperature fluctuations in vertical profiles and temperature fronts with sharp horizontal gradients have been observed in the vicinity of the marginal ice zone of the Chukchi Sea. See, for example, La Fond and Pritchard (1952), Paquette and Bourke (1979) and Garrison and Becker (1975). With the advent in recent years of submarines operating in shallow, ice-covered waters, the processes occuring in the marginal ice zone and their effects on underwater acoustic propagation have come to be of considerable interest to the United States Navy.

Oceanographic conditions prevailing in and near the ice of the Chukchi Sea have been investigated by personnel from the Naval Postgraduate School and Applied Physics Laboratory, University of Washington in conjunction with the MARGINAL SEAICE ZONE PACIFIC (MIZPAC) program. Since 1971 the Arctic Submarine Laboratory, Naval Ocean systems Center, San Diego has sponsored six MIZPAC cruises to the Chukchi sea during the summer ice-melt season. During each of these cruises continuously profiling temperature-salinity instruments have recorded temperature fluctuations (termed finestructure) with a peak-to-peak amplitude often exceeding $2^{\circ} \mathrm{C}$ over a vertical extent of the order of several meters. Observations of 

temperature fronts with horizontal gradients of up to $2^{\circ} \mathrm{C} / \mathrm{km}$ have also been reported to exist along the ice edge (Graham, 1978).

The occurrence of these phenomena in the chukchi sea in mid-summer led to speculation on the possibility of their occurrence during the winter and spring when the ice is farther south, in the Bering sea. The temperature contrasts were not expected to be large under such conditions; but the presence of temperature fronts was considered possible. MIZPAC data has shown that notable finestructure in the chukchi sea has occasionally occurred when a temperature contrast between the interleaving waters of only $1^{\circ} \mathrm{C}$ was present. Therefore, it was assumed that if fronts possessing contrasts of this order were formed in the Bering Sea, the presence of finestructure was possible. A further discussion of the oceanographic conditions leading to the formation of finestructure and temperature fronts is presented in section I.C.

Because there have been no oceanographic cruises in the Bering sea dedicated to this study, indications of conditions conducive to the formation of finestructure were sought in the historical reversing-bottle data in the archives of the National Oceanographic Data Center (NODC). Because the likelihood of detecting finestructure itself is small in discrete data such as these, indications of thermal fronts were sought instead. If notable fronts existed, notable finestructure would be considered likely to exist also. 

NODC temperature and salinity data for the months February through June were examined. Data from these months characterize the oceanographic conditions present just prior to and during the ice-melt season, the most likely period for the development of temperature fronts and finestructure.

In addition to the search for fronts near the ice, the large temporal and spatial distribution of data also made possible some observations about convective processes in ice covered waters and about the strength of wind mixing in ice free waters.

\section{B. OBJECTIVES}

Within the limitations inherent in the use of historical hydrographic data for oceanographic analysis, to be discussed in section II.C, the following objectives for this research were established:

1. Determine if the oceanographic conditions in the Bering sea are conducive to the formation of temperature fronts and temperature finestructure as observed in the Chukchi Sea.

2. Examine the bottom water characteristics in the Bering sea in order to determine if it could be a possible source for the high salinity, underice bottom water observed in the Chukchi sea during the summer months.

3. Determine the relative importance of convective mixing, resulting from the brine rejection process during 

freezing, in establishing the water mass characteristics in and near the ice.

C. FINESTRUCTURE AND TEMPERATURE FRONTS IN THE CHUKCHI SEA

The following is a brief review of the conditions leading to the formation of finestructure and temperature fronts in the Chukchi Sea as reported by Paquette and Bourke (1978) and Graham (1978).

The ice-melt season in the Chukchi Sea begins in mid-June as the main pack of sea ice retreats northward through Bering Strait. Melting initially takes place at a rapid rate as the warm waters $\left(4-7^{\circ} \mathrm{C}\right)$ flowing northward from Bering strait provide thermal energy at the ice edge. From Bering strait northward surface temperatures have been observed to rise $2-3^{\circ} \mathrm{C}$ before cooling occurs upon reaching the ice margin. Insolation accounts for only 10-20\% of the energy required to account for the observed recession rate (Paquette and Bourke, 1979) so the impact of the warm current appears to be the major influence in melting processes along the ice edge. By late July the southern edge of the ice has receded to about $70^{\circ} \mathrm{N}$ latitude. It is in this region that most of the MIZPAC observations have been made.

As the warm waters from Bering Strait flow northward, thermal stratification begins to appear. Approximately $100 \mathrm{~km}$ from the ice edge in the central Chukchi sea salinity stratification develops. The temperatures in the surface layer are between $4^{\circ}$ and $10^{\circ} \mathrm{C}$ and are separated from the colder 

bottom waters by a sharp thermocline. In the lower layer, which Paquette and Bourke (1978) have termed "southern bottom water," temperatures are reported to be no colder than $-1.3^{\circ} \mathrm{C}$ and salinities less than or equal to $32.6^{\circ} \% 0$. The underice area of the Chukchi sea is dominated by a cold, high-salinity water of distinctly different properties than those to the south. This water is also two-layered with the lower layer extending from the sea floor to within a few meters of the surface. The "northern bottom water" has salinities greater than $32.8 \%$ and temperatures generally between $-1.60^{\circ} \mathrm{C}$ and $-1.80^{\circ} \mathrm{C}$ (Paquette and Bourke, 1978). Graham (1978) reports salinities between $33.0^{\circ} / 00$ and $33.8^{\circ} / 00$.

The warm surface layer of southern water coming in contact with the ice and the resulting colder melt water produces sharp temperature and salinity fronts which extend to approximately $15 \mathrm{~m}$ depth. They form everywhere along the marginal ice zone.

The area of contact between the bottom waters of these two regions is of primary concern because it is within this zone that the formation of most of the finestructure occurs. The lower-layer fronts resulting from this contact have been seen to occur in two locations relative to the surface front, either coincident with it or displaced away from it towards open water.

Graham (1978) and Paquette and Bourke (1978) conclude that there is a geographic distribution of these fronts which is coupled with the direction of flow. A strong component of flow in the surface layer which is normal to the ice was 

found to favor the formation of uncoupled temperature fronts with the lower front displaced towards open water. When currents had a strong component of flow parallel to the ice edge, the formation of vertical coincident temperature fronts was more likely.

The formation of finestructure, because it is primarily found in association with the deeper front, has a similar distribution relative to the ice edge. Finestructure itself is formed when interleaving of two water masses of different temperatures occurs along a surface of similar density.

D. GENERAL OCEANOGRAPHY OF THE BERING SEA

1. Topography of the Bering sea

The most striking feature of the Bering sea is the dichotomy of bathymetric features between the eastern and western halves of the sea. The broad shallow continental shelf (Figure 1), where depths in excess of $50 \mathrm{~m}$ are rarely encountered (except in the Gulf of Anadyr), occupies approximately $44 \%$ of the sea floor (Hood and Kelly, 1974). Dominating the north central shelf area is St. Lawrence Island, located southeast of Cape Chukotski between the two major embayments of the shelf area, the Gulf of Anadyr on the Siberian coast and Norton Sound on the Alaskan coast. Because of its position, the island acts to impede the general northerly flow and produces a lee effect noticeable at least $150 \mathrm{~km}$ to the north (Coachman et al., 1975). 

The shallow water of the continental shelf is influenced by the extreme gradients of climate that are endemic to subarctic regions. Intense winter and spring storms, the freezing and melting of ice, river runoff, and the extreme variation of solar insolation provide the dynamics for widely varying oceanographic conditions.

The western $43 \%$ of the sea floor is comprised of two abyssal plains, the Aleutian Basin and the Kamchatka Basin, separated by the Shirshov Ridge-Bower Ridge complex (Hood and Kelly, 1974). Here, depths of up to $3800 \mathrm{~m}$ are encountered. Except along the northern extremes where the presence of sea ice influences the water column, the oceanographic conditions in winter and spring here appear to be mainly influenced by cooling and atmospheric disturbances.

The continental slope extends from Cape Navarin in the northwest to Unalaska Island in the southeast and acts as a barrier to the free exchange of water from the deep basins to the continental shelf. This is especially true in the winter and spring when the surface layers of the deep basins have experienced a large loss of heat. During these months, the continental slope inhibits any major transport of the warmer, but denser bottom waters of the deep basins onto the shelf. This situation is illustrated in Figure 2, which is a cross-section of temperature and density obtained by USCGC BURTON ISLAND in February 1972 along a section that crosses the continental slope (Section F25 in Figure 4). 



\section{Ice Distribution and Behavior}

By October, ice has started to form in the rivers along the northern shores and is fast to the shore in most harbors and bays by November. Sea ice normally passes through Bering Strait during November and rapidly advances southward to its maximum extent in March or April. The southern limit of the main pack roughly parallels the continental slope along the southern and western boundaries. However, it is established at a more northerly position over the southeastern shelf as a result of the warm water influx of the Alaskan Stream through the eastern passages of the Aleutian Islands (Gershanovitch et al., 1974).

Fay (1974) describes the southern limit as a zone $15-65 \mathrm{~km}$ wide in which the ice is broken up into broad bands and rafts of brash, small floes, and pancake ice interspersed with areas of open water. The varied configurations of the ice within the zone results from the intermittent effects of the winter and spring storms.

The ice achieves its heaviest and thickest concentrations southwest and north-northeast of St. Lawrence Island (McRoy and Goering, 1974). The thickness grades from a maximum of 1 to 2 meters in ridge-free flows to near zero at the southern limit during freezing conditions.

Ice breakup and recession begins in March or April and the retreat is rapid and irregular toward the north, normally passing through Bering strait during mid-June (NAVOCEANO, 1958 ). Lisitsyn (1966) found that approximately $63 \%$ of the ice melts within the confines of the Bering 

Sea and that the remainder is transported through the Bering or Kamchatka Straits and the Aleutian passes.

\section{Currents and Water Masses}

Numerous circulation schemes have been proposed for the Bering Sea. With the exception of Natarov (1963), they are derived from summer measurements. Natarov's winter scheme (Figure 3) depicts a cyclonic gyre encompassing the entire Aleutian Basin. Relatively warm $\left(3^{\circ}-4^{\circ} \mathrm{C}\right)$ Alaskan stream water enters the Bering through the eastern passes of the Aleutians, and is either picked up in the above mentioned cyclonic gyre or flows directly towards the southeastern shelf. The validity of this scheme is supported by the findings of Hughes, Coachman and Aagaard (1974) and Dobrovol'skii and Arsen'ev (1959).

winter circulation on the continential shelf is largely unknown. Coachman et al. (1975) believe that present evidence points towards a predominantly northerly flow pattern similar to that in summer.

Based on summer observations, Coachman et al.

identify three basic water masses of the Bering Shelf:

Anadyr Water, Bering Shelf water and Alaskan Coastal water. Anadyr water is hypothesized to be derived from water in the deep basins which travels northwest parallel to the continental slope as a subsurface extension of the Bering slope Current entering the Gulf of Anadyr in a narrow band close to shore. The analysis of the 1972 THOMPSON data by Coachman et al. (1974) identify this subsurface flow into the Gulf 

of Anadyr as water of nearly constant salinity (32.8\%) and temperature (between $1.75^{\circ} \mathrm{C}$ and $2^{\circ} \mathrm{C}$ ). Anadyr Water results from the mixing of this water with the colder, more saline water of the central Gulf of Anadyr.

Bering Shelf Water appears to originate south of St. Lawrence Island as a mixture of warm saline water from the deep basins and the very cold (less than $1^{\circ} \mathrm{C}$ ), low salinity (less than $32.5 \%$ water which is seen to occupy a large area southwest of St. Lawrence Island throughout the year. This "cold spot" has also been described by Barnes and Thompson (1938) and Kitano (1970). Characteristic temperatures and salinities for Bering shelf water are $-0.5^{\circ} \mathrm{C}$ to $1^{\circ}$ or $2^{\circ} \mathrm{C}$ and 32.5 to $32.8 \%$ respectively. Bering shelf Water is observed to bifurcate to the south of St. Lawrence Island and flow northward on both sides of St. Lawrence Island.

The third major water mass of the shelf is Alaskan Coastal Water. During the summer it is the warmest and least saline of the three. It is a horizontally stratified water mass formed from cold water $32 \%$ of salinity through dilution by fresh water runoff from the Alaskan coast and warming by solar insolation.

Winter water mass conditions are simplified by strong vertical mixing and atmospheric cooling. In the deep basins atmospheric cooling and wind mixing result in horizontally stratified water with a surface layer of nearly homogeneous temperature and salinity. 

On the continental shelf in open water, wind mixing and atmospheric cooling create vertically mixed columns. These processes maintain water temperatures at or close to freezing. Under the ice, convective mixing is active and creates equally well mixed vertical columns. Some observation on this subject will be made in section III.B. 



\section{PROCEDURES}

A. DATA SOURCE

This analysis was based on historic oceanographic data for Marsden squares 197 through 200, and 233 through 235 . The data were obtained from the National Oceanographic Data Center (NODC). Table I summarizes the cruises from which data were analyzed.

B. DATA REDUCTION

A series of five programs written by R. G. Paquette, R. H. Bourke or this author were utilized extensively in the data reduction for this thesis. The original volume of stations in these Marsden squares numbered over 7900. In order to select only those stations of interest, two computer programs NODCRD MOD2 (R. G. Paquette, 1978) and NODPUN (W. R. Lohrmann, 1978) were written to provide for the retrieval of selected data from the NODC tape and for the punching of data cards to be used in further analysis.

The task of analyzing the data could not begin until the selected stations were geographically plotted. To do this CHTPLT MOD 6, a modified version of a program adapted by R. H. Bourke from an earlier plotting program by R. G. Paquette, was utilized. Before the program could be used, it was required that its capability be expanded in order to accommodate the plotting of stations in eastern longitudes. 



\section{TABLE I}

\section{SUMMARY OF OCEANOGRAPHIC CRUISES}

FROM WHICH DATA WERE EXAMINED

\begin{tabular}{|c|c|c|c|}
\hline Year & Dates & Vessel & Area \\
\hline 1951 & February & BURTON ISLAND & $\begin{array}{l}\text { East, north and west } \\
\text { of St. Lawrence I. }\end{array}$ \\
\hline 1954 & May & BURTON ISLAND & $\begin{array}{l}\text { Prifilof Islands to } \\
\text { Bering Strait, east } \\
\text { of St. Lawrence I. }\end{array}$ \\
\hline 1955 & March-April & NORTHWIND & $\begin{array}{l}\text { East, southeast and } \\
\text { northeast of St. } \\
\text { Lawrence I. }\end{array}$ \\
\hline 1955 & May & BURTON ISLAND & $\begin{array}{l}\text { Northeast and south- } \\
\text { east of St. Lawrence } \\
\text { I. }\end{array}$ \\
\hline 1960 & February & STATEN ISLAND & $\begin{array}{l}\text { From Pribilof Islands } \\
\text { north to St. Matthew I } \\
\text { and west of St. } \\
\text { Matthew I. }\end{array}$ \\
\hline 1961 & April & PERVENETS & $\begin{array}{l}\text { Between Pribilof } \mathrm{I} \text {. } \\
\text { and Aleutian I. }\end{array}$ \\
\hline 1966 & February & ARGO & Western Bering Sea \\
\hline 1968 & February & NORTHWIND & $\begin{array}{l}\text { Gulf of Anadyr and } \\
\text { Strait of Anadyr }\end{array}$ \\
\hline 1969 & $\begin{array}{l}\text { February-March } \\
\text { April }\end{array}$ & STATEN ISLAND & $\begin{array}{l}\text { East, south and west } \\
\text { of St. Lawrence I.; } \\
\text { north through Bering } \\
\text { Strait }\end{array}$ \\
\hline 1969 & June & NORTHWIND & $\begin{array}{l}\text { St. Lawrence I. to } \\
\text { north of Bering Strait }\end{array}$ \\
\hline 1970 & February & NORTHWIND & $\begin{array}{l}\text { Northwest from Bristol } \\
\text { Bay to south of Cape } \\
\text { Navarin; east to south } \\
\text { of St. Lawrence I. }\end{array}$ \\
\hline 1970 & March-April & MILLER FREEMAN & Bristol Bay \\
\hline 1972 & February-March & BURTON ISLAND & $\begin{array}{l}\text { Unalaska to Pribilof } \\
\text { I. to west of St. } \\
\text { Matthews I. to St. } \\
\text { Lawrence I. }\end{array}$ \\
\hline
\end{tabular}



From the selected stations 104 cross-sections were idenfified. The task of hand drawing contours of temperature, salinity and density for each section was out of the question, so computer analysis was employed. CONTRA 3, a modified version of a program written by R. G. Paquette, provided for computerized contouring of these properties. CONTRA 3 utilizes the library subroutine CONISD written by R. Hillary and L. Nolan for the W. R. Church Computer Center, Naval Postgraduate School. CONISD utilizes Versatec plotting hardware and software. While much time can now be saved through the use of this subroutine, the process of contouring the data was a very time consuming task. The CONISD subroutine had, and still has, some subtle deficiencies which caused considerable difficulty. It was particularly likely to fail, drawing meaningless isopleths, when the data density was low. Most of the problems were eventually solved by program modifications, by the occasional addition of data points, and by the occasional use of manual corrections to the isopleths.

The final program in the series was TS PLOT, a program written by the author to present temperature-salinity relationships for each section and for their comparison with the freezing point line. This display was used in inferring the location of the ice edge.

\section{DATA LIMITATIONS}

Several limitations in the use of historic hydrographic data in a search for evidence of temperature finestructure were recognized and considered in this analysis: 

1. As mentioned earlier, the likelihood of actually finding finestructure in discrete data such as that obtained from reversing thermometers is quite small. Thermal fronts, which can be indicators of finestructure formation zones, can be easily recognized if the station spacing is sufficiently small.

2. Oceanographic conditions at the bottom were usually not available. Most of the casts reached within 10-15 meters of the sea floor (except in the deep basins where this separation increased). In all cases, it was assumed that the conditions at the bottom were the same as at the deepest bottle. This assumption was made to permit the automatic contouring program to carry the isopleths and the figure frame to the reported bottom depth. Isopleths were then manually corrected to compensate for the assumption. Little or no error is likely to have resulted from the procedure, except in shallow waters where brine pools may exist in the bottom $5 \mathrm{~m}$ of the water column. The degree of interpolation will be evident on the property sections to be shown later by noting that where interpolated data has been added, the isopleths have been drawn with a dashed line.

3. The position of the ice edge relative to selected sections is not recorded in the data and must be inferred from the presence of near-freezing conditions in the surface water. In this analysis the temperature-salinity characteristics at each station were compared against the freezing point determined by Thompson (1932) from which the existence of ice was then inferred. 

Vertical sections of temperature, salinity and sigma-t obtained from original (non-interpolated) station data were produced for 104 cross-sections, from February through June. The location of these sections are shown by month in Figures 4 through 8. The inserts shown in Figures 4 through 6 are are reproduced in a larger scale and appear as Figures 9 through 11, respectively. These latter figures enclose the area in which analysis was concentrated. Sections outside of these areas were also examined and incorporated where appropriate.

Displaying each cross-section obtained would have been counterproductive to the objectives of this thesis. Hence, only those sections which most clearly characterized the conditions in and near the ice were included.

Each section was identified with an alpha-numeric designation which consists of a code letter for the month in which the data were obtained and a sequential number purely for identification. For example, section F8 is a February section, M8 a March section, and so on. Station numbers were provided by the author, if they were not contained in the NODC data.

As mentioned in Section II.B.3, the library subroutine CONISD was utilized in preparing the sections for analysis. Because the automatic contouring subroutine breaks down when data is sparse or when a data point is missing, it was occasionally necessary to introduce an artificial data point by interpolation. The occurrence of this situation was rare 

and was considered to have no deleterious effect on the results obtained.

The property intervals used in displaying the data are shown in Table II. Due to the small interval between contours, minor variations in properties were occasionally distorted in plotting. In such cases minor additional smoothing of the isopleths was done. The reader will also note that in some cases, salinity sections are shown and at other times density sections. In waters near the ice, wherein temperatures are only moderately above freezing, the density is primarily influenced by the salinity. Therefore, the isopleths of salinity and density nearly coincide in orientation.

TABLE II

CONTOUR INTERVALS AND LIMITS USED IN PLOTTING

Property

Temperature

Salinity

Sigma-t
Contour Interval

$$
{ }^{\circ} \mathrm{C}
$$$$
0.1^{\circ} \mathrm{C}
$$

$0.2 \%$

0.25
Limits

$8^{\circ} \mathrm{C}$ to $-1.0^{\circ} \mathrm{C}$

$-1.3^{\circ} \mathrm{C}$ to $-1.8^{\circ} \mathrm{C}$

$31.4 \%$ to $34.4 \%$

25.25 to $27.75^{\circ} / 00$ 



\section{RESULTS}

Discussion of the oceanographic conditions observed will be presented in three parts. In section $A$, the existence of temperature fronts and the possibility of finestructure will be discussed. In Section B, observations concerning underice processes will be presented, as well as some comments on the extent of vertical mixing outside of the ice. Section $C$ will be directed towards the question of whether or not the Bering sea might be a source of bottom water found in the Chukchi sea during the mid-summer.

A. TEMPERATURE FRONTS

If the conclusions of Graham (1978) and Paquette and Bourke (1978) concerning the geographic distribution of fronts and finestructure can be extrapolated to the Bering Sea, then the formation of coincident type fronts is most likely to occur in the zone from $170^{\circ} \mathrm{W}$ to $175^{\circ} \mathrm{E}$ where the component of warm surface flow is strongest parallel to the established ice edge. Likewise, eastward from $170^{\circ} \mathrm{W}$ where Natarov's currents appear more normal to the ice, the likelihood of finding surface as well as non-coincident deep fronts should be the greatest.

The geographic and temporal distribution of observed temperature fronts is shown in Figure 12. The position of a front is indicated by a bold line perpendicular to the 

section in which it was observed except in a few places where one could believe the front to be long and oriented along the direction of flow. The maximum and minimum temperatures observed immediately adjacent to the front are also shown. Three temperature fronts with gradients between $.01^{\circ} \mathrm{C} / \mathrm{km}$ and $.05^{\circ} \mathrm{C} / \mathrm{km}$ were observed in the data for February and March.

Temperature and density Section F25 (Figure 13) shows a surface front with a maximum thermal gradient of $.057^{\circ} \mathrm{C} / \mathrm{km}$. The maximum temperature gradient can be seen to occur in a region of nearly constant density, i.e., the front is density compensated. This situation is favorable to the interleaving of waters of different temperatures. However, because of the small horizontal thermal gradient, a lateral intrusion of $3.5 \mathrm{~km}$ extent would have to occur in order for finestructure having a peak-to-peak fluctuation of the order of $0.2^{\circ} \mathrm{C} / \mathrm{km}$ to exist. The existence of finestructure is a possibility in this situation; however, the likelihood of its occurrence is small due to the weak gradient resulting from the small temperature contrast across the broad front.

Temperature Section Ml (Figure 14) shows a deep front observed to the northwest of St. Matthew Island on the central shelf. A maximum gradient of $.038^{\circ} \mathrm{C} / \mathrm{km}$ occurs near the bottom. With a gradient weaker than that observed in Section F25, one would expect an even smaller likelihood of finestructure than in that example.

The third front observed in this group occurred in the Gulf of Anadyr and was evident in Sections Fl through F7 

(Figure 4). Tempeature section F2 (Figure 15) is shown to illustrate the situation. Here a maximum horizontal temperature gradient of $.02^{\circ} \mathrm{C} / \mathrm{km}$ exists on both the eastern and western ends of the section.

It should be noted that the fronts in section F2 and $\mathrm{MI}$ appear to result from a northwestward-flowing warm stream, whereas the front in section F25 seems to be the result of a flow directly northward from the eastern Aleutian passes. This analysis is consistent with the general circulation scheme discussed in section I.D. 3 for the winter months. The northwestward flow which is the source of warmth in Sections $\mathrm{ML}$ and $\mathrm{F} 2$ is believed to be the Bering slope Current carrying Bering Sea basin water to the Gulf of Anadyr as suggested by Coachman et al., (1975). The existence of this warm flow was observed in several other sections. Temperature and salinity sections F19 (stations 119 and 120), F20 (station 117) and F2l (stations 114 and 115) all show a core of warm water below $50 \mathrm{~m}$ with similar temperature and salinity characteristics $\left(0^{\circ} \mathrm{C}\right.$ to $1.0^{\circ} \mathrm{C}$ and $37.5^{\circ} / 00$ to $\left.32.8^{\circ} / 00\right)$. The position of these observations is shown in Figure 12.

In April the continuity of the warm flow was observed in Section AlO between stations 11 and 12 , and in Section A9 between stations 19 and 22. Section A9 (Figure 16) contains a distinct warm core at the bottom. The temperature gradients on both sides of the core are comparable to those of the deep fronts found in Section Ml.

It seems apparent that each of the fronts observed from February through April, with the exception of the front 

observed in section $\mathrm{F} 25$, resulted from the interaction of the subsurface extension of the Bering Slope Current with the colder water of the ice covered shelf.

Although no May or June data which would provide further evidence of the frontal activity along the shelf edge was available, it is assumed to persist in some form. Koto and Maeda (1965) report a northward shift of the interface between the cold water from the north and the warm water from the deep basin from late April to late June.

A comprehensive analysis of the oceanographic conditions prevailing in May was limited because of sparse salinity and density data. Frontal activity was not observed in any of the sections shown in Figure 12 although vertical temperature stratification was prevalent. The temperatures, somewhat surprisingly, were not much warmer than in the previous months with temperatures below $0^{\circ} \mathrm{C}$ common and no indication of significant heat input to the areas sampled. Temperature and salinity Section MAl6 (Figure 17) reveal the similarity between the May data and that of the previous months. Indications of the development of horizontal temperature and salinity stratification were evident in several sections, but these were not the predominant conditions. Evidence of the presence of river water is seen in this section but it is not enough to cause stratification.

It was not until June that the oceanographic conditions changed dramatically. Frontal activity was the strongest observed in all months investigated. This was not unexpected as it is in June that the conditions in the Bering sea are 

most nearly like those of the Chukchi sea one to two months later. Temperatures observed showed no signs of the presence of ice and were remarkably higher than those observed in May. The influence of Yukon River input was evident, as salinities below $30.0 \%$ were recorded. These low values were confined to the eastern margins of the Bering Sea. Horizontal stratification was seen to be developing throughout the sampled area but was not yet dominant.

Evidence of temperature fronts were observed in each of the six June cross-sections shown in Figure 12. Temperature Sections J1 (Figure 18) and J2 (Figure 19) are examples of the thermal fronts observed. In section $J 1$ the deep front results from the intrusion of cold $\left(-1.6^{\circ} \mathrm{C}\right.$ to $\left.-1.7^{\circ} \mathrm{C}\right)$, high salinity $\left(32.4^{\circ} / 00\right.$ to $\left.32.9^{\circ} / 00\right)$ water from the strait of Anadyr. The front in section J2 appears as a result of warm water influx from the Alaskan coastal water.

The complexity of the temperature and salinity regimes in each of the sections and their similarities to those observed in the Chukchi Sea indicate that finestructure formation is apparently likely during this month.

\section{B. UNDER ICE PROCESSES AND WIND MIXING}

Active vertical mixing in open water was evident from February through May. The data showed that top to bottom mixing can occur in water at least up to 80 meters deep. For example, top to bottom mixing was observed in density sections located in the Gulf of Anadyr (Section F2, Figure 20), 

on the continental shelf east of St. Lawrence Island (Section M7, Figure 21), on the southeast shelf (Section Al6, Figure 22), and on the northern shelf (Section MAl6, Figure 23). These examples were not isolated instances, but an indicative of several occurrences observed in each of the months and areas.

Strong under ice convective mixing was also evident in almost all ice-covered locations. Again refering to density Section F2 (Figure 20), we see that eastward of station 25, under the ice, convective mixing has maintained the vertical density structure. The slight departures from the vertical all can easily be due to measurement errors.

Another aspect of the results of active brine rejection is that of the creation of brine drainage paths along the bottom in the very shallow waters close to shore where, because of the decreased depth, salinities produced by brine rejection are higher. As mentioned in section II.C.2, the original data did not extend to the bottom and therefore the characteristics of the water within $10-15 \mathrm{~m}$ of the bottom are inferred from the deepest sampled values. Consequently, no evidence of high density pools was seen in the data; however, density sections F6, F7 and F8 in the Gulf of Anadyr showed characteristics of downward sloping isopycnals, a feature suggestive of down-slope brine drainage. As an example, salinity section $\mathrm{F} 6$ is shown in Figure 24 . Here the slope of the isopycnals is clearly evident, indicative of the possible downward drainage of the high salinity water. The 

three sections mentioned above are the only examples of this phenomenon noted in the data.

\section{BOTTOM WATER OBSERVATIONS}

The purpose of conducting this portion of the analysis was to determine if the under-ice "northern bottom water" of the Chukchi Sea discussed in section I.C. could possibly have its origin in the Bering sea. Since there appears to be little water exchange from the deep basins to the continental shelf except into the Gulf of Anadyr, the analysis was limited to the continental shelf waters. Comparing the salinity characteristics of these shelf waters during April and May with those of the Chukchi sea during mid-summer should serve to show if this hypothesis is correct, for it is these waters which travel northward during early spring through Bering Strait and fill the bottom of the Chukchi Sea.

As was discussed in Section I.C., "northern bottom water" has characteristic salinities between $32.8 \%$ and $33.8 \%$. If the Bering sea is the source of this high salinity bottom water, salinities greater than $32.8 \%$ should be common on the northern shelf of the Bering Sea. Coachman et al. (1975) discuss the winter data obtained from the April 1969 cruise of USCGC STATEN ISLAND. The highest salinities observed were $33.1 \%$ occuring near the central Gulf of Anadyr. South of St. Lawrence Island salinities were between $32.3^{\circ} / 00$ and $32.6 \%$ and east of $\mathrm{St}$. Lawrence they were the lowest, less than $32.7 \%$. The only one of these waters with salinity high 

enough for consideration is the central Gulf of Anadyr water which is believed to hug the Siberian coast occupying only a narrow band along the western shore of Bering strait. The data for May were also examined for evidence of northern bottom water. Although salinity data were available for only $50 \%$ of the sections north of St. Lawrence Island, the salinities recorded were consistently below $32.4 \%$, well below the $32.8 \%$ oo required if it is the source region.

Based on the qualitative observations mentioned, it seems quite unlikely that the high salinity northern bottom water of the Chukchi Sea originates per se in the Bering Sea. However, it would be possible for water of moderate salinity in mid-winter to be enriched with brine during its course northward (assuming that it goes north) and reach the higher salinities of the Chukchi sea in the northern Bering Sea and southern Chukchi Sea. 


\section{CONCLUSIONS}

The historical data available for the winter and spring months in the Bering sea were graphically displayed and analyzed providing evidence for the following conclusions:

- The formation of temperature fronts during the winter is limited to the area along the southern edge of the continental shelf. These fronts are extremely weak and considered to be unlikely sites for the formation of finestructure.

- Temperature fronts formed in Bering strait and immediately south of the Strait in June are of sufficient strength and character to be considered likely sites for the formation of finestructure.

- The high salinity under ice bottom water observed in the Chukchi sea during the summer does not have its origins in the Bering sea unless the water is salified during its trip north.

- The processes of convective mixing, due to brine rejection, and of wind mixing in open water appear to dominate throughout the winter and spring. Horizontal mixing is extremely weak resulting in vertically mixed water columns in nearly all the data analyzed. 




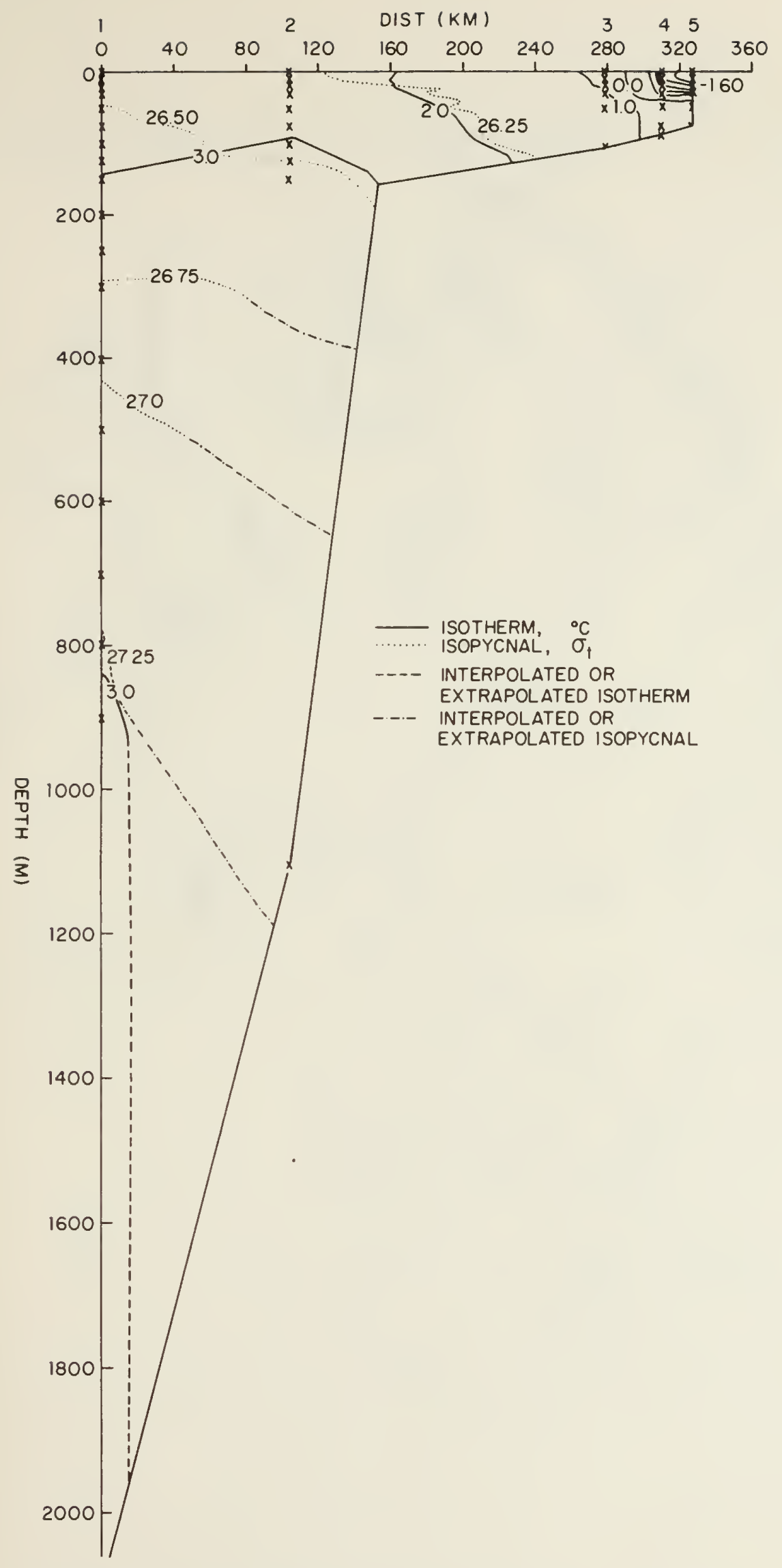

Figure 2. Temperature and density crosssection F25. USCGC BURTON ISLAND, February 1972. Section oriented south to north. 




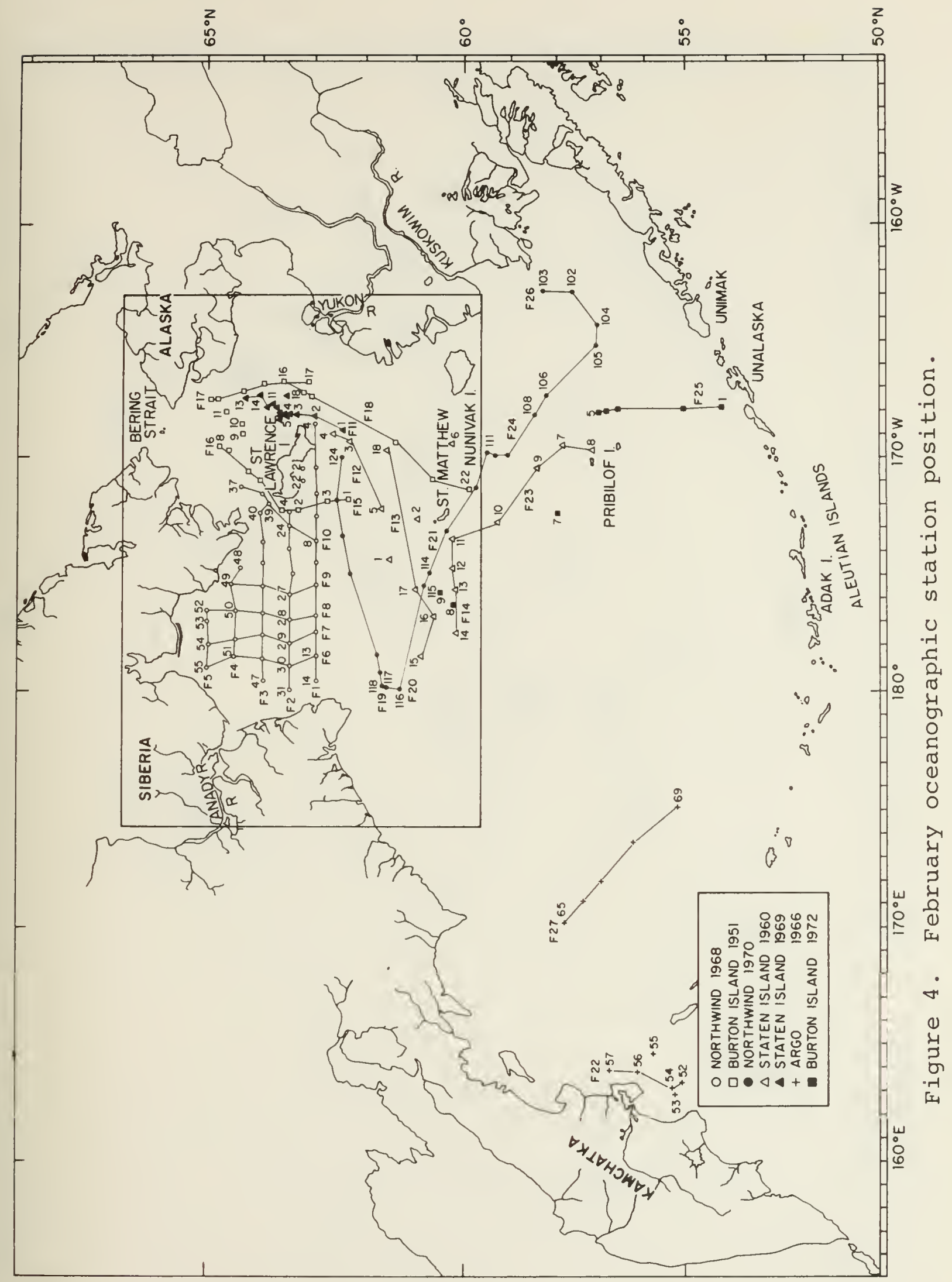





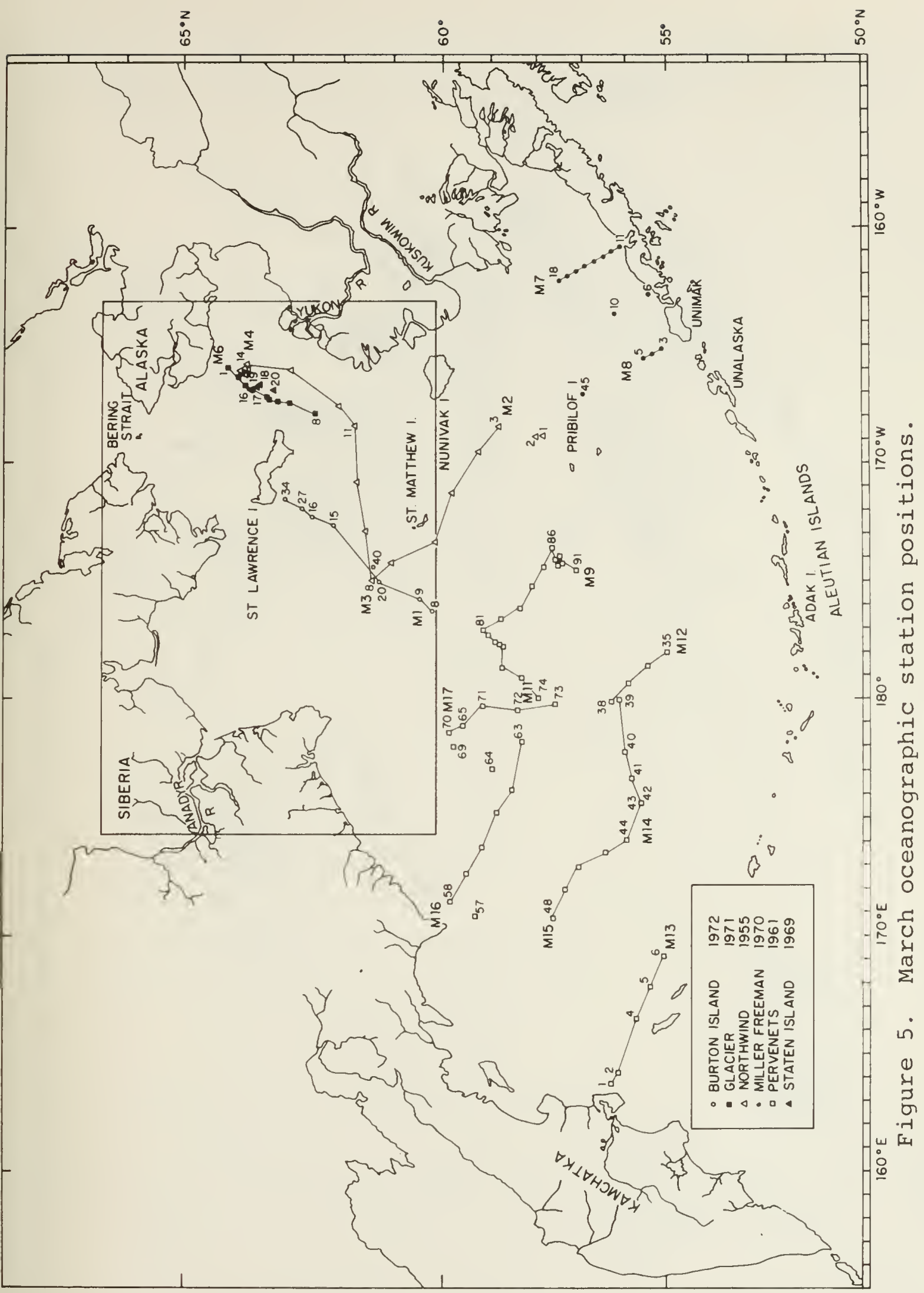





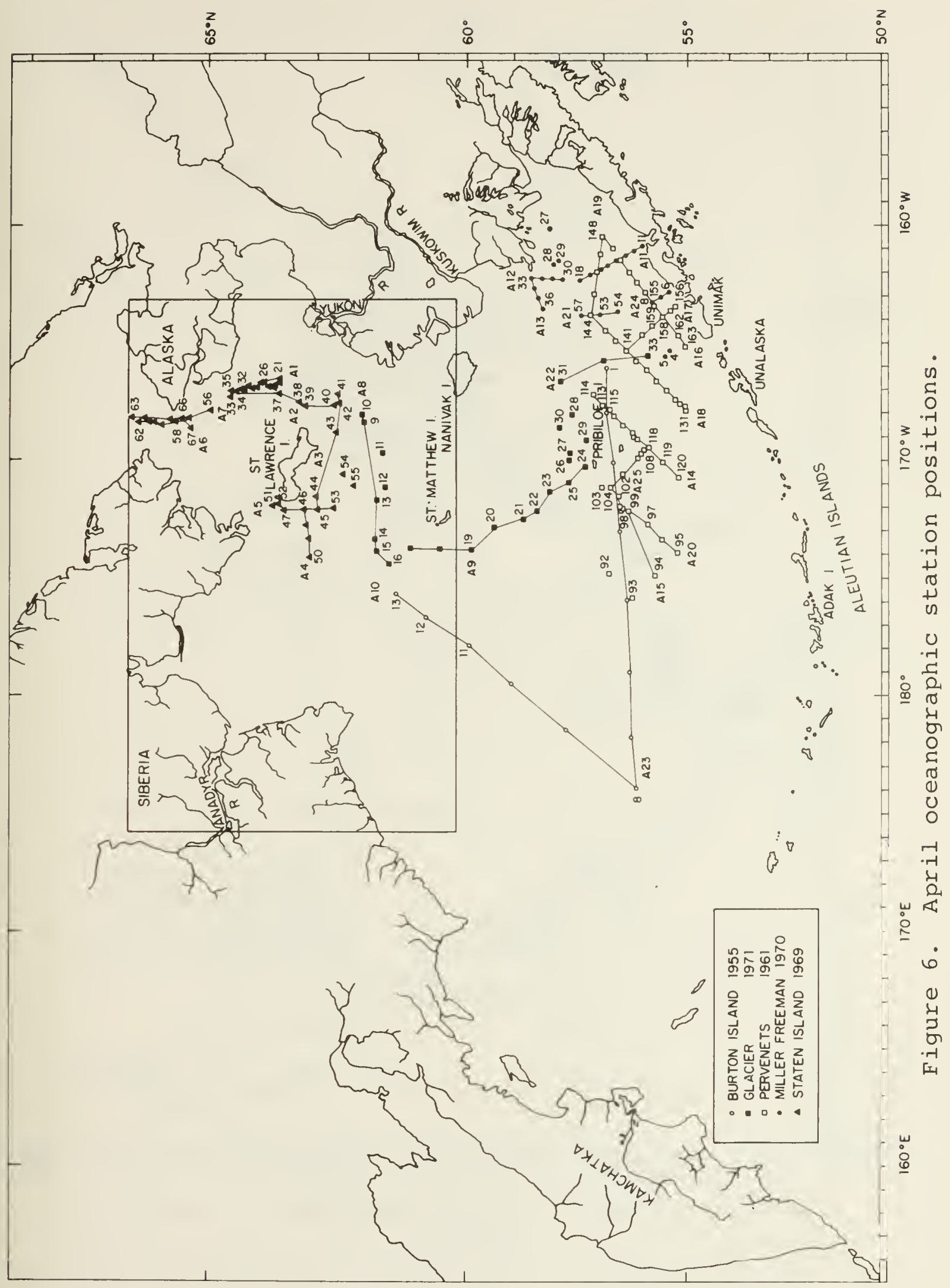





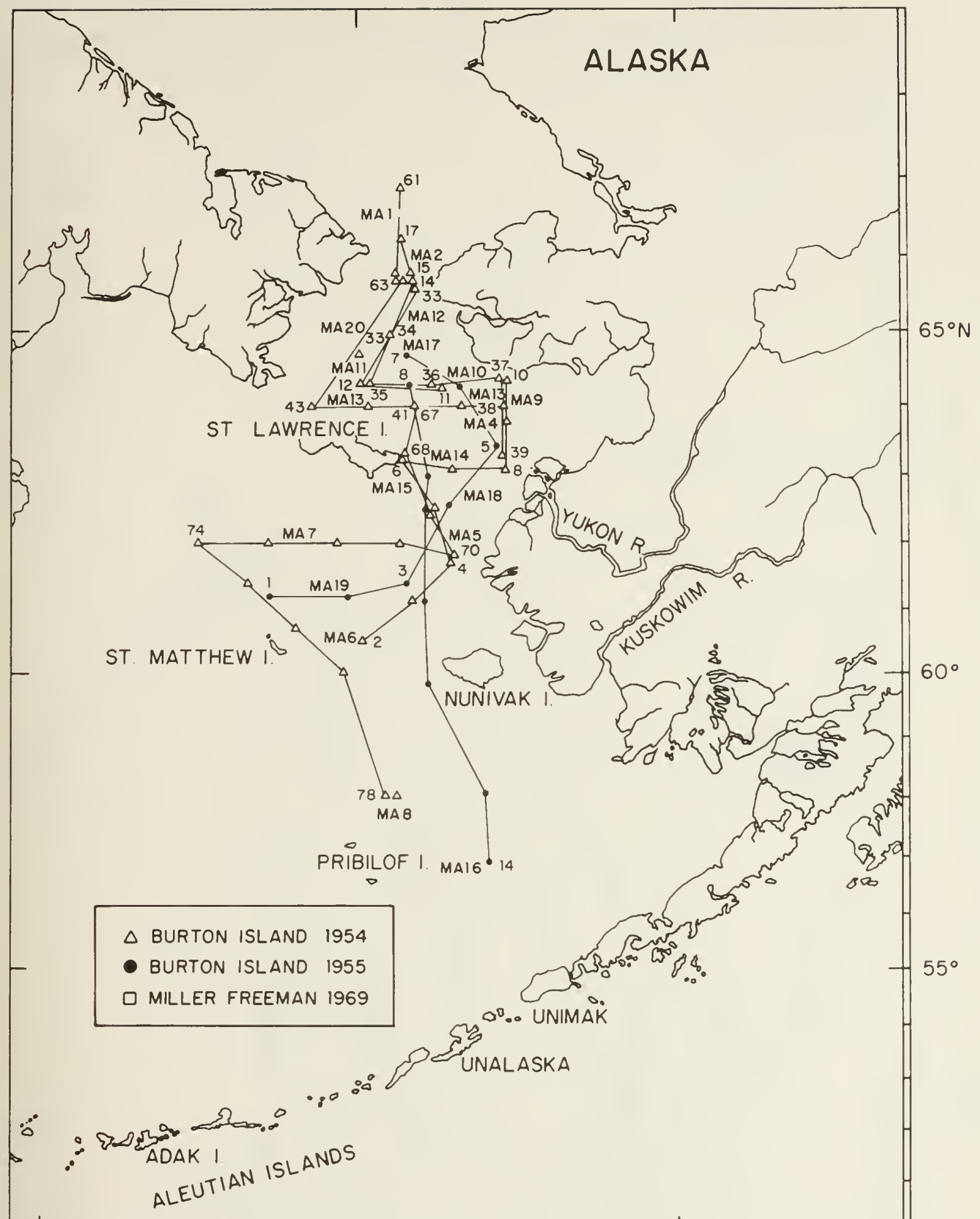

$180^{\circ} \quad 170^{\circ} \mathrm{W} \quad 160^{\circ} \mathrm{W}$

Figure 7. May oceanographic station positions. 



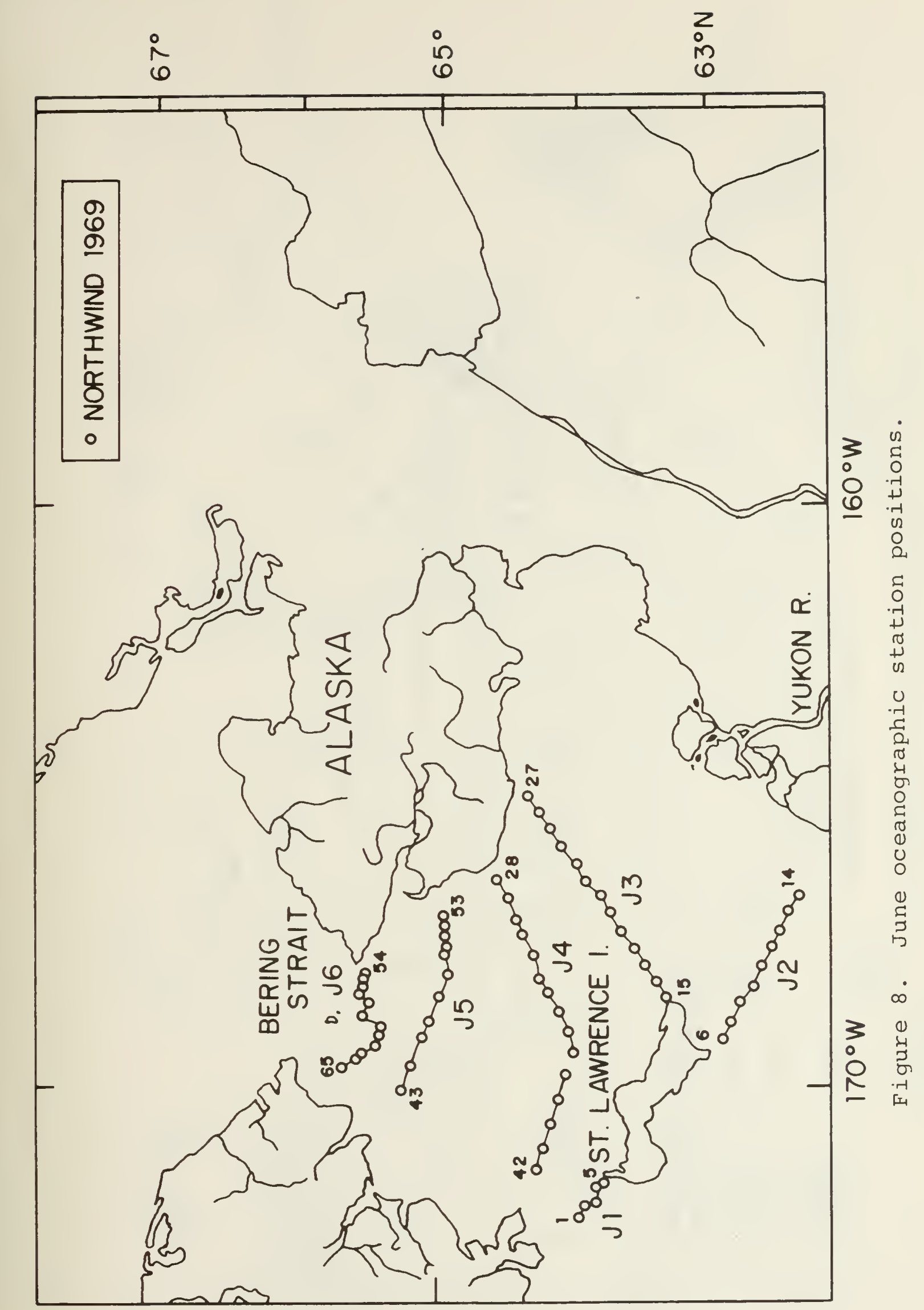





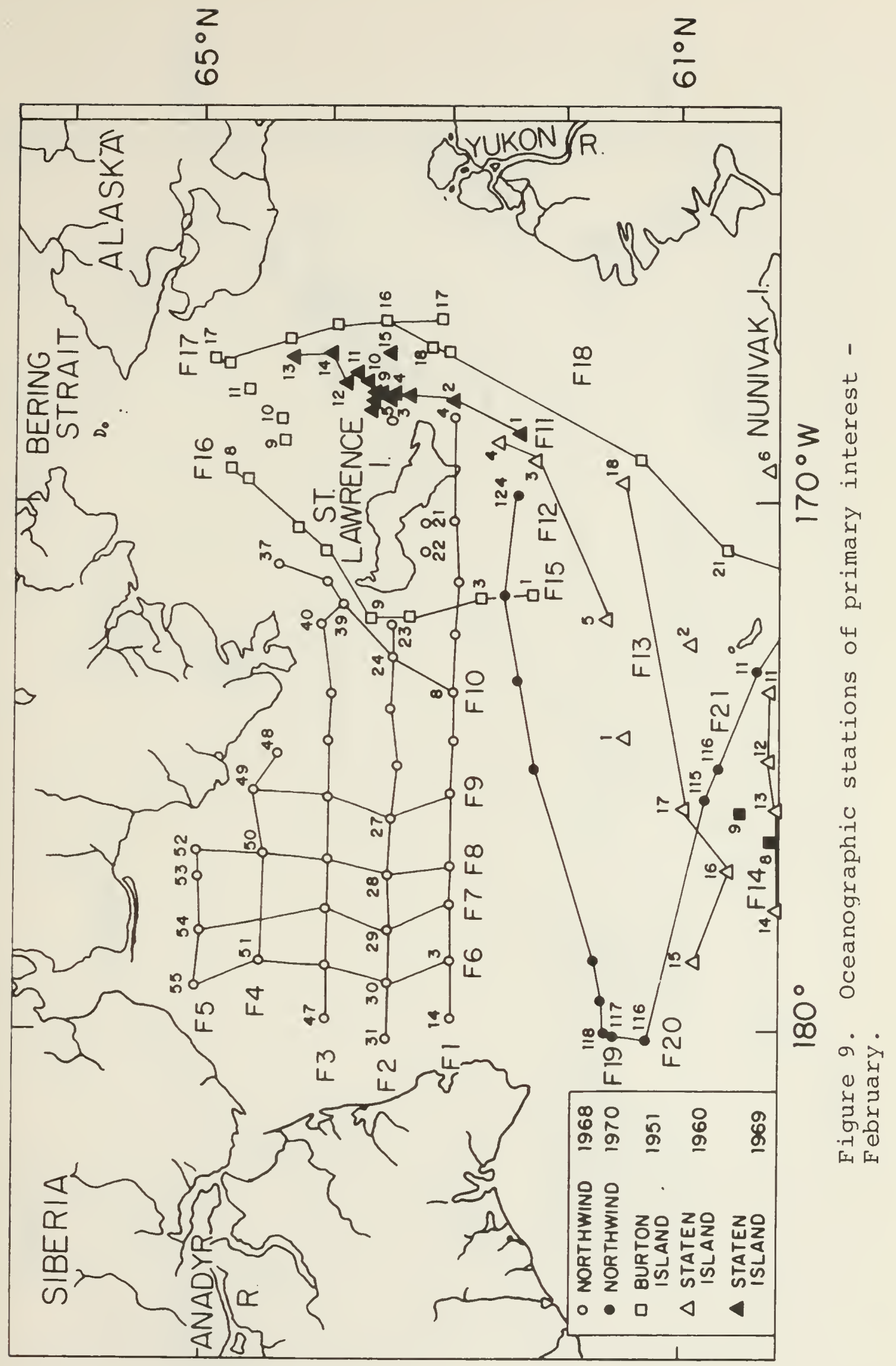




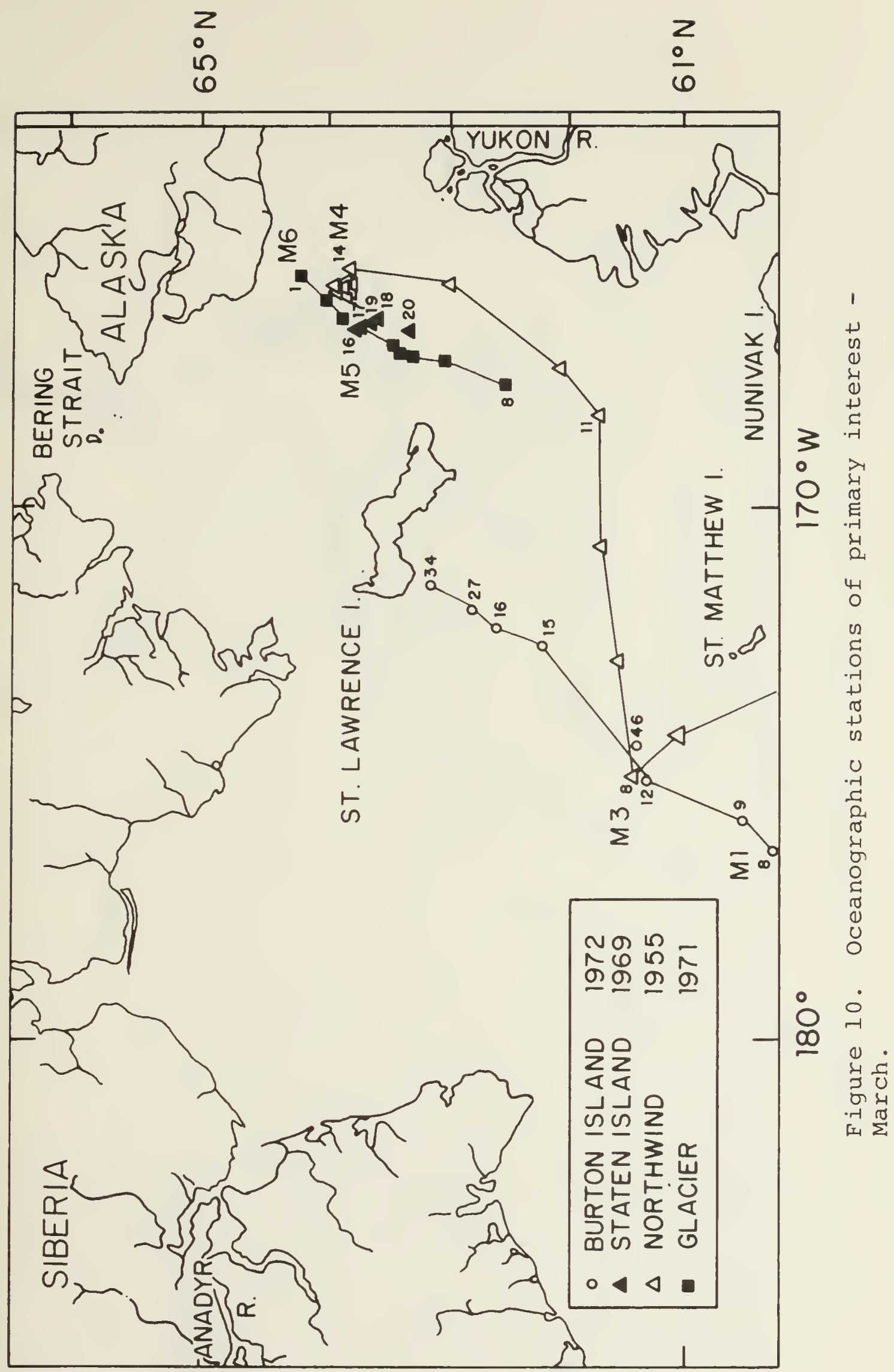



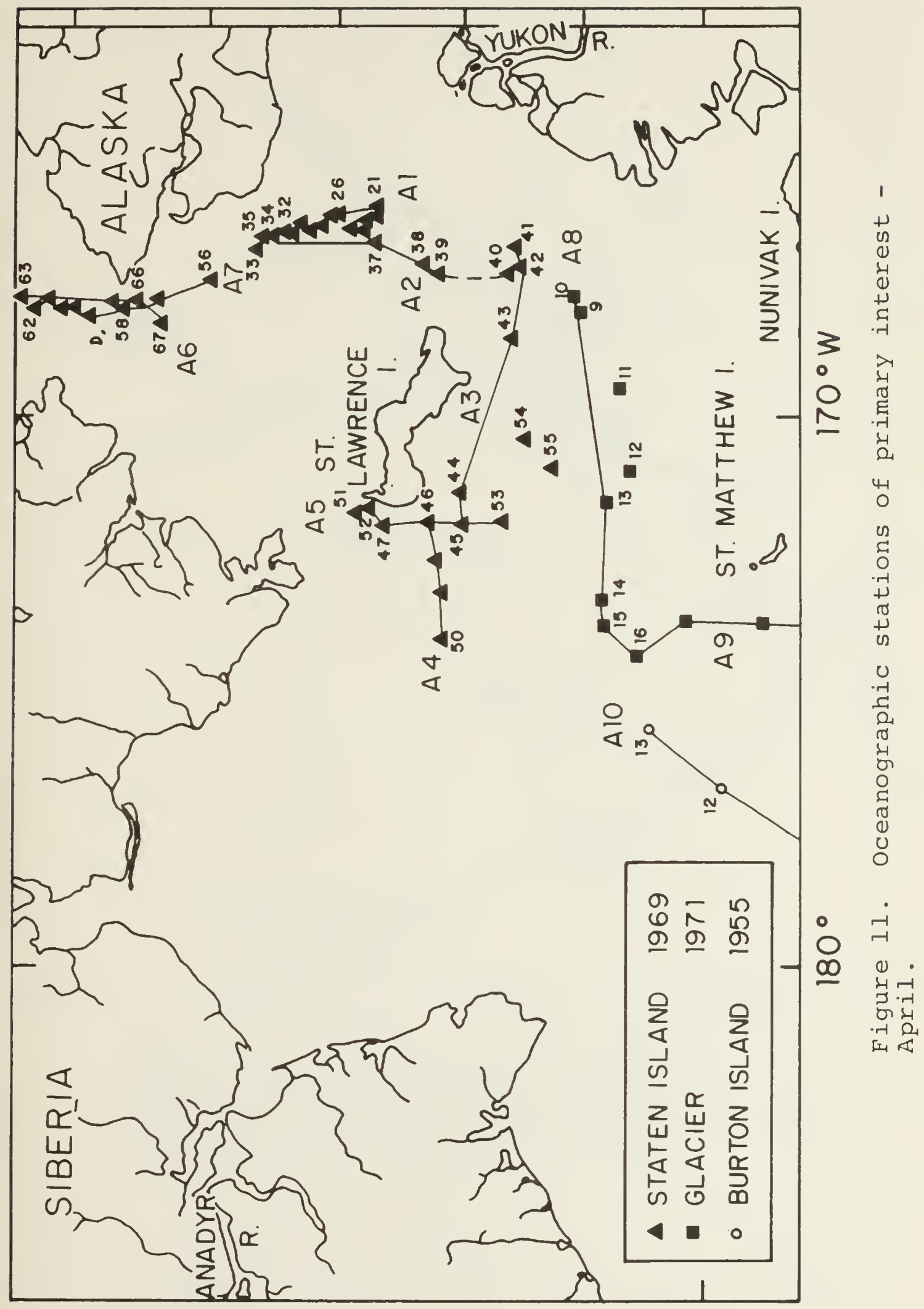





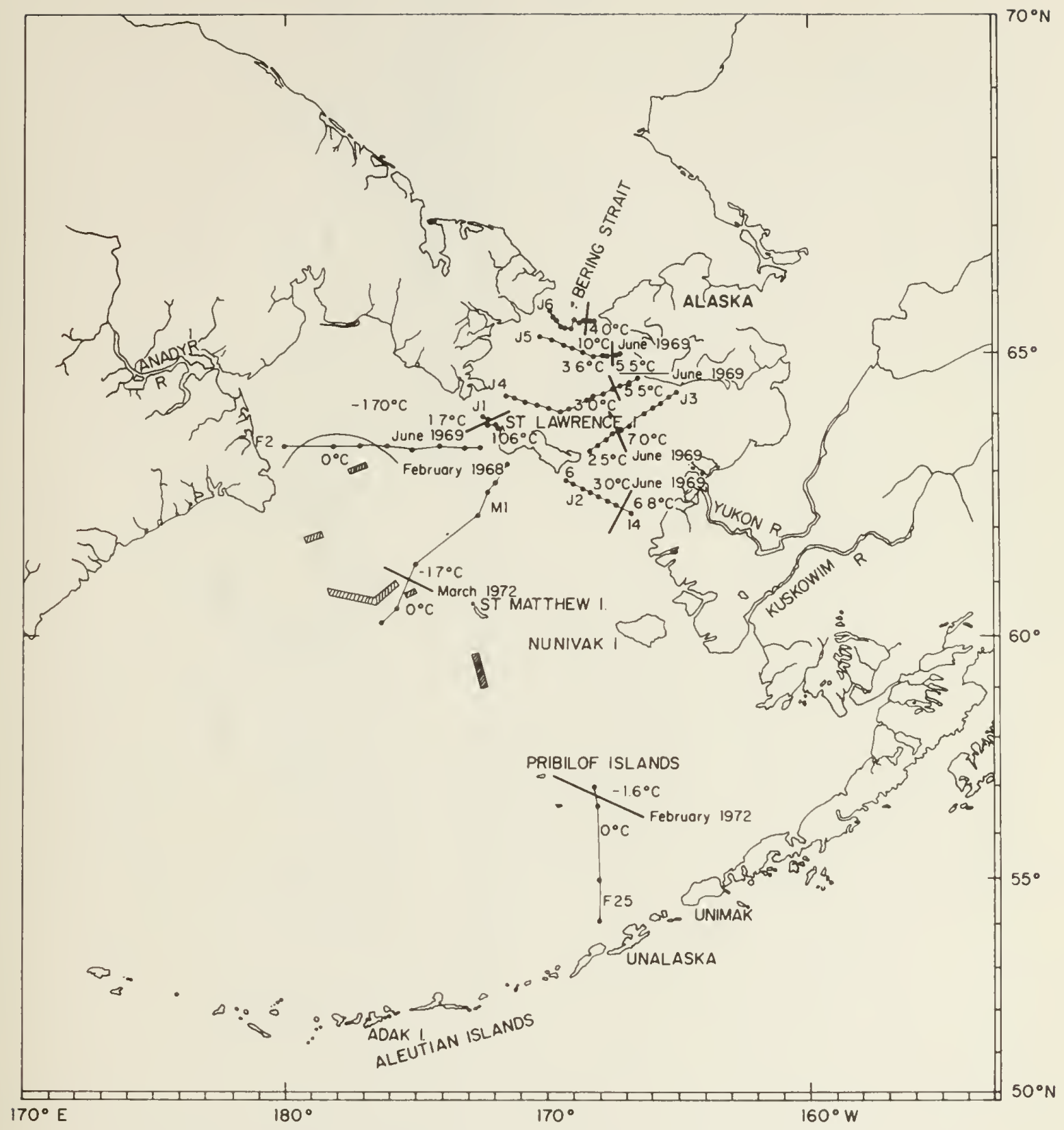

Figure 12. Temperature front distribution and location of warm water observations. Bold line indicates inferred orientation of front. Hatched areas indicate positions of sub-surface warm water observations. 



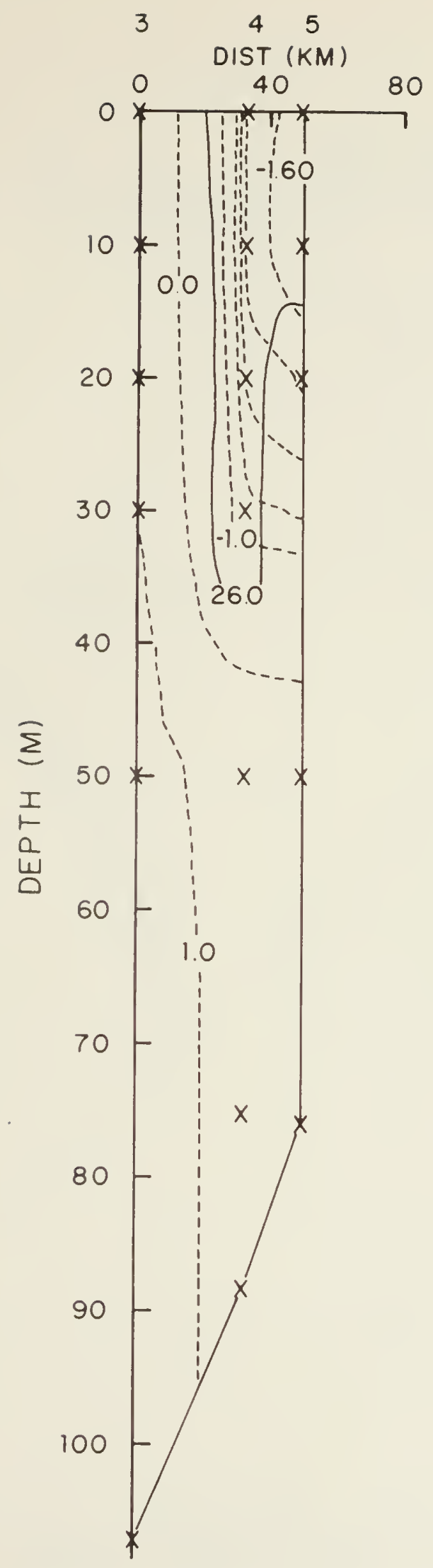

Figure 13. Temperature and salinity cross-section F25 (Stations 3, 4, and 5). USCGC BURTON ISLAND, February 1972 . 



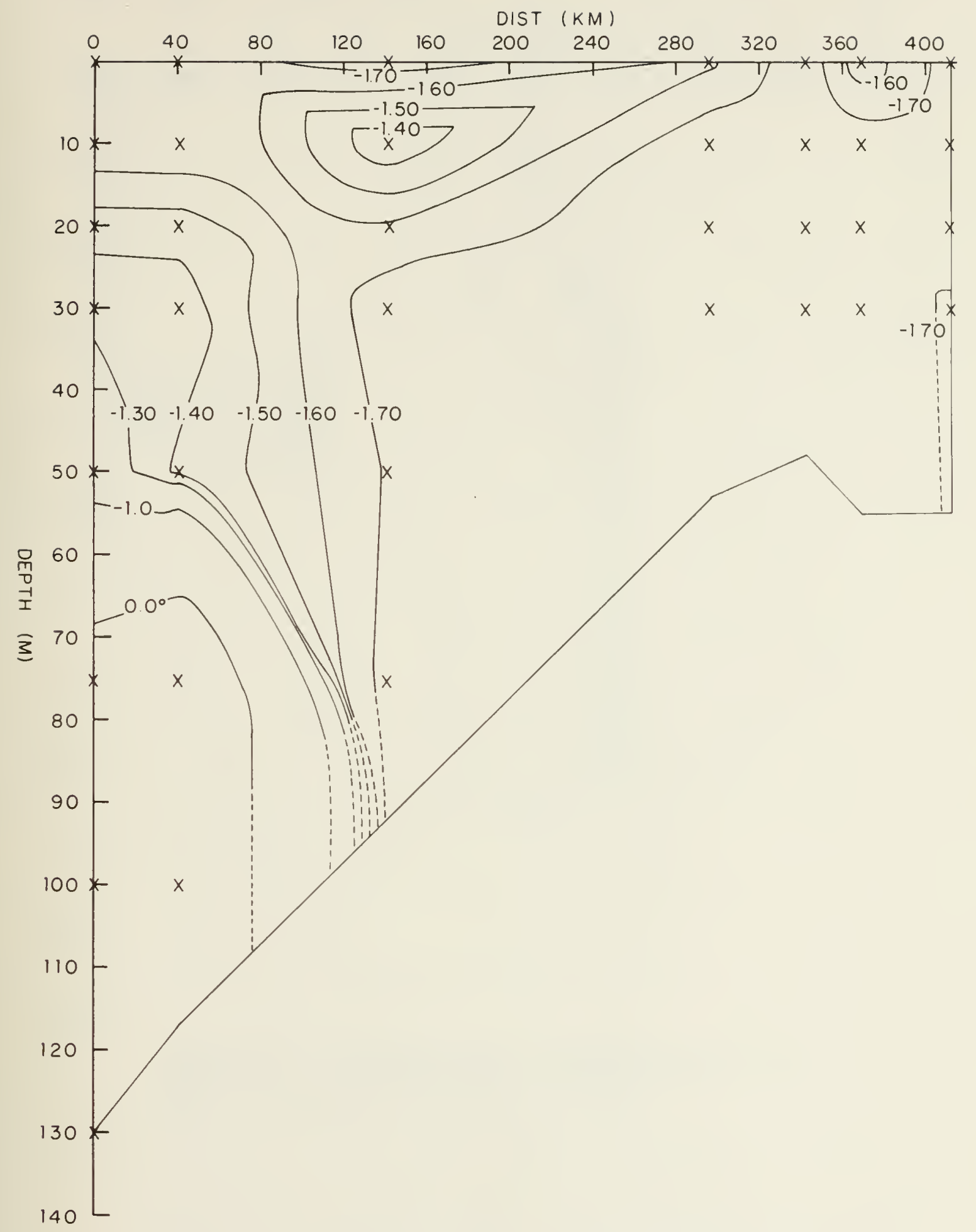

Figure 14. Temperature cross-section Ml. USCGC BURTON ISLAND, March 1972. 



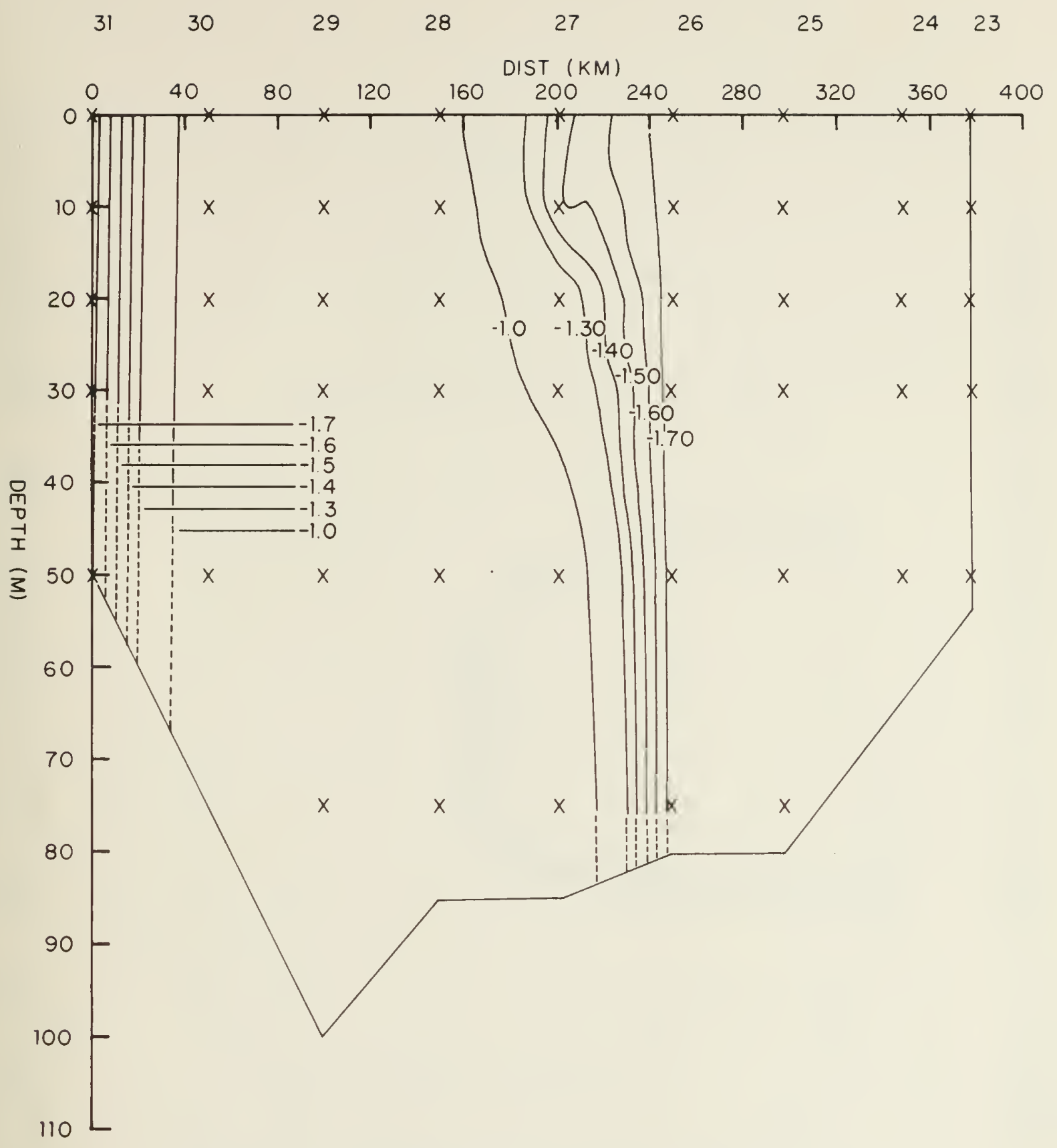

Figure 15. Temperature cross-section F2. USCGC NORTHWIND, February 1968. 



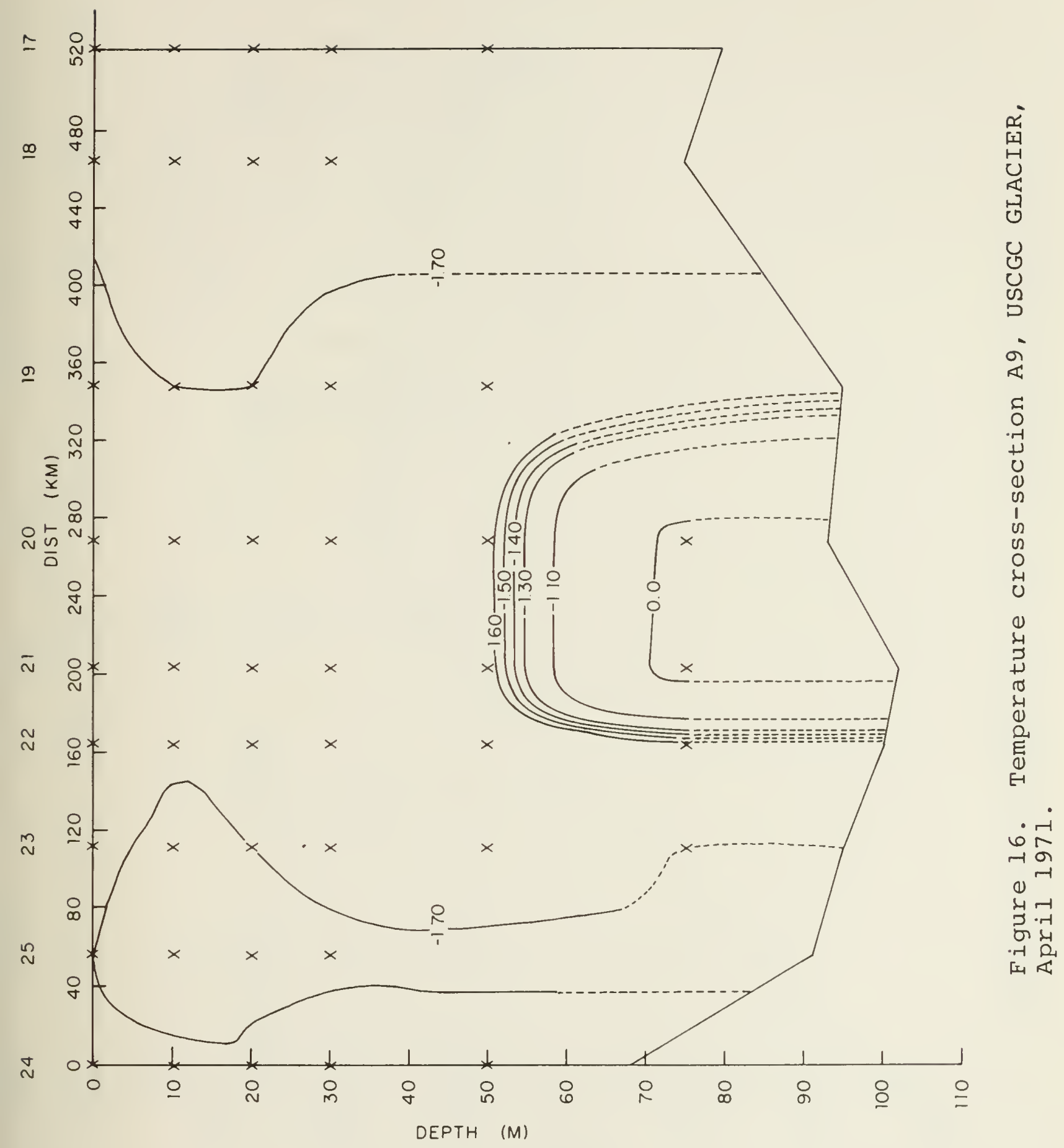





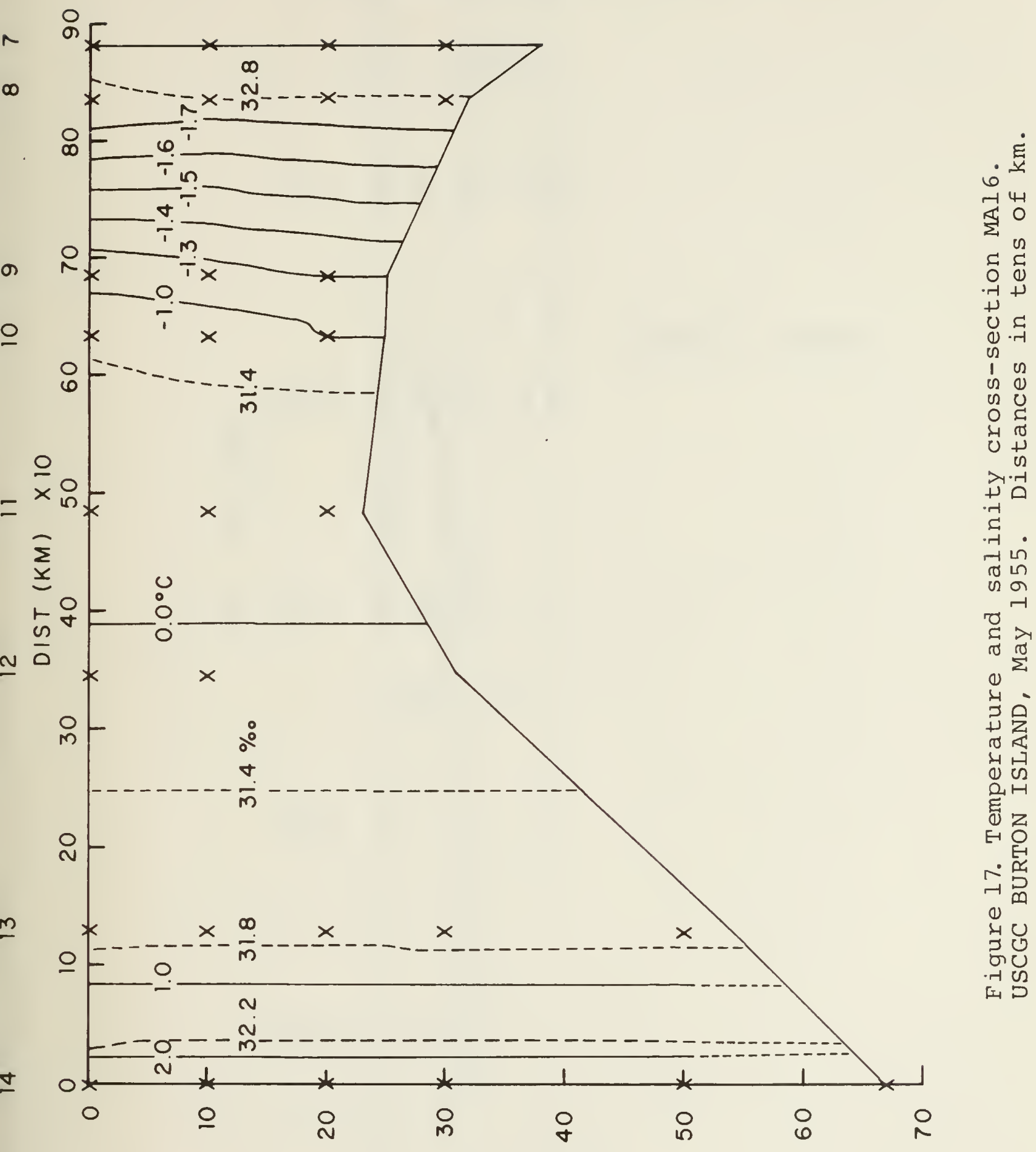

(W) $H \perp d \exists O$ 



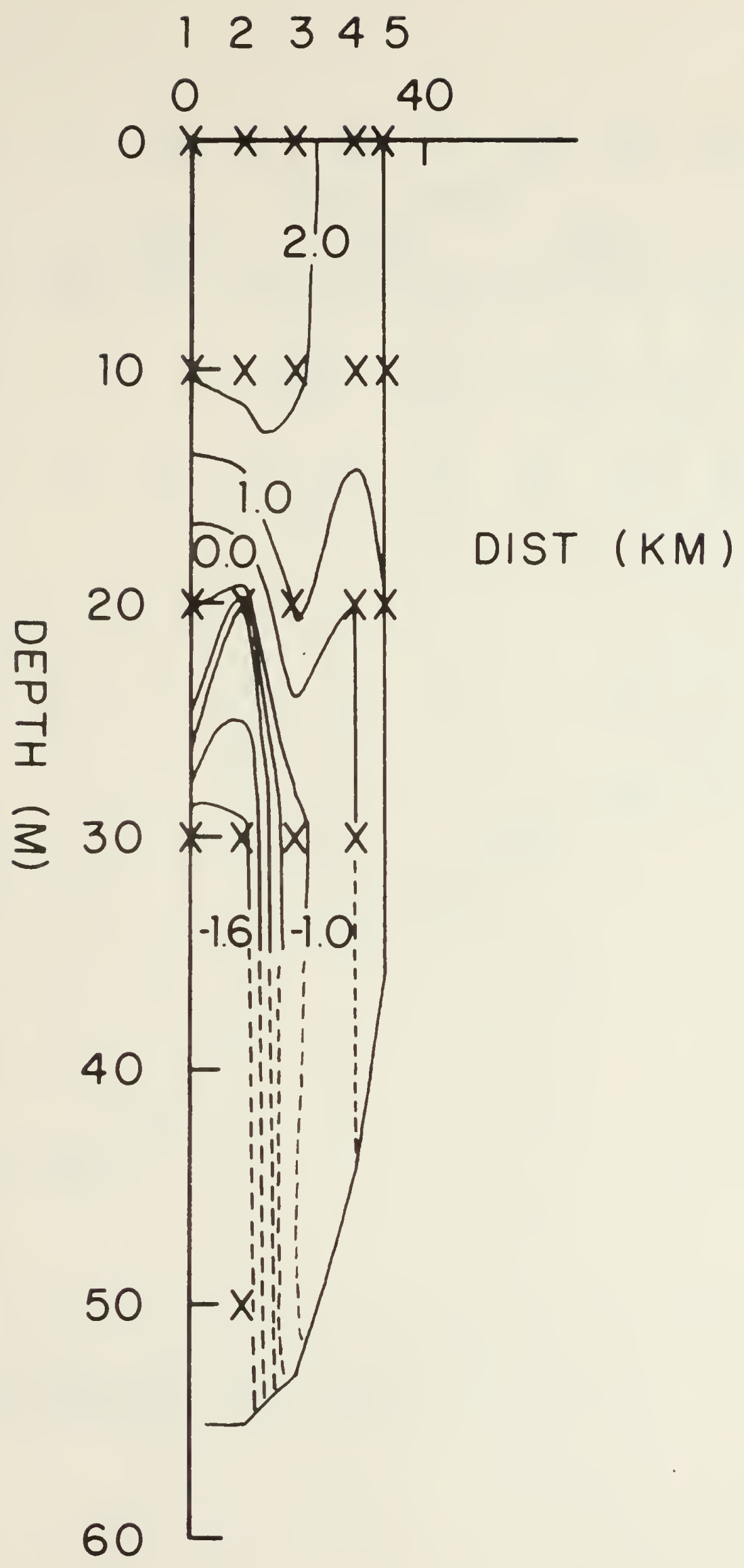

Figure 18. Temperature cross-section Jl. USCGC NORTHWIND, June 1972. 



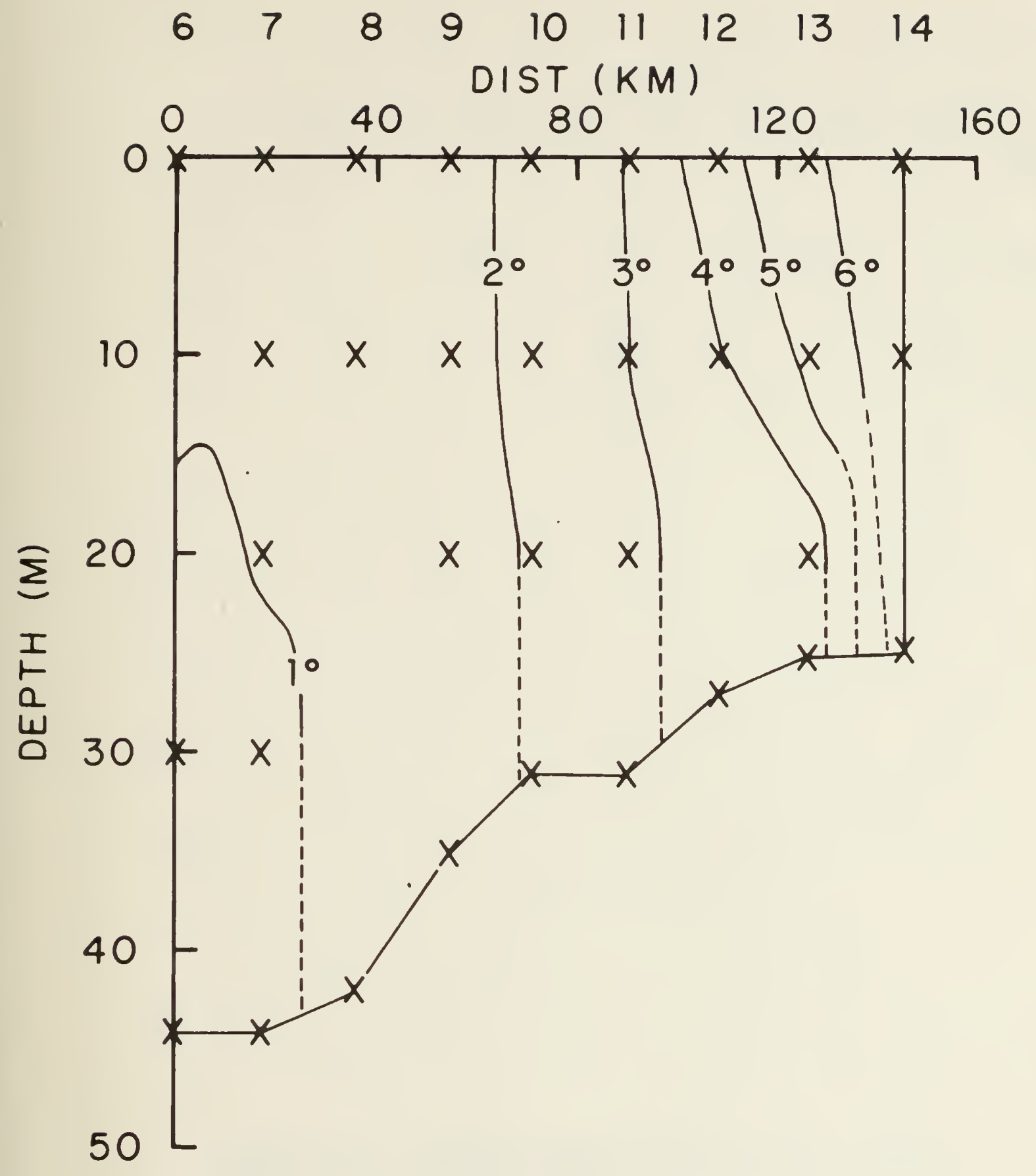

Figure 19. Temperature cross-section J2. USCGC NORTHWIND, June 1972. 



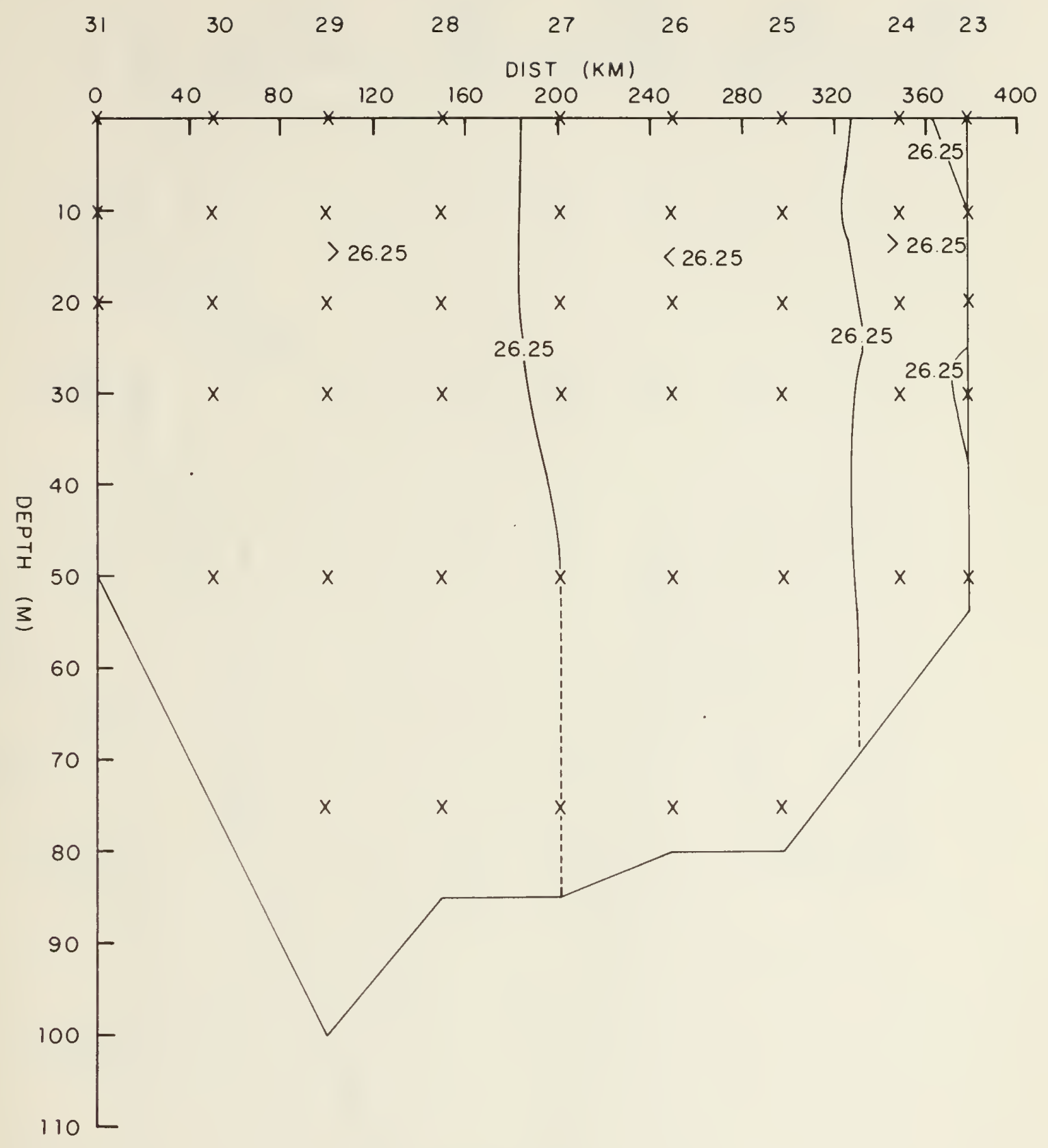

Figure 20. Density cross-section F2. USCGC NORTHWIND, February 1968. 



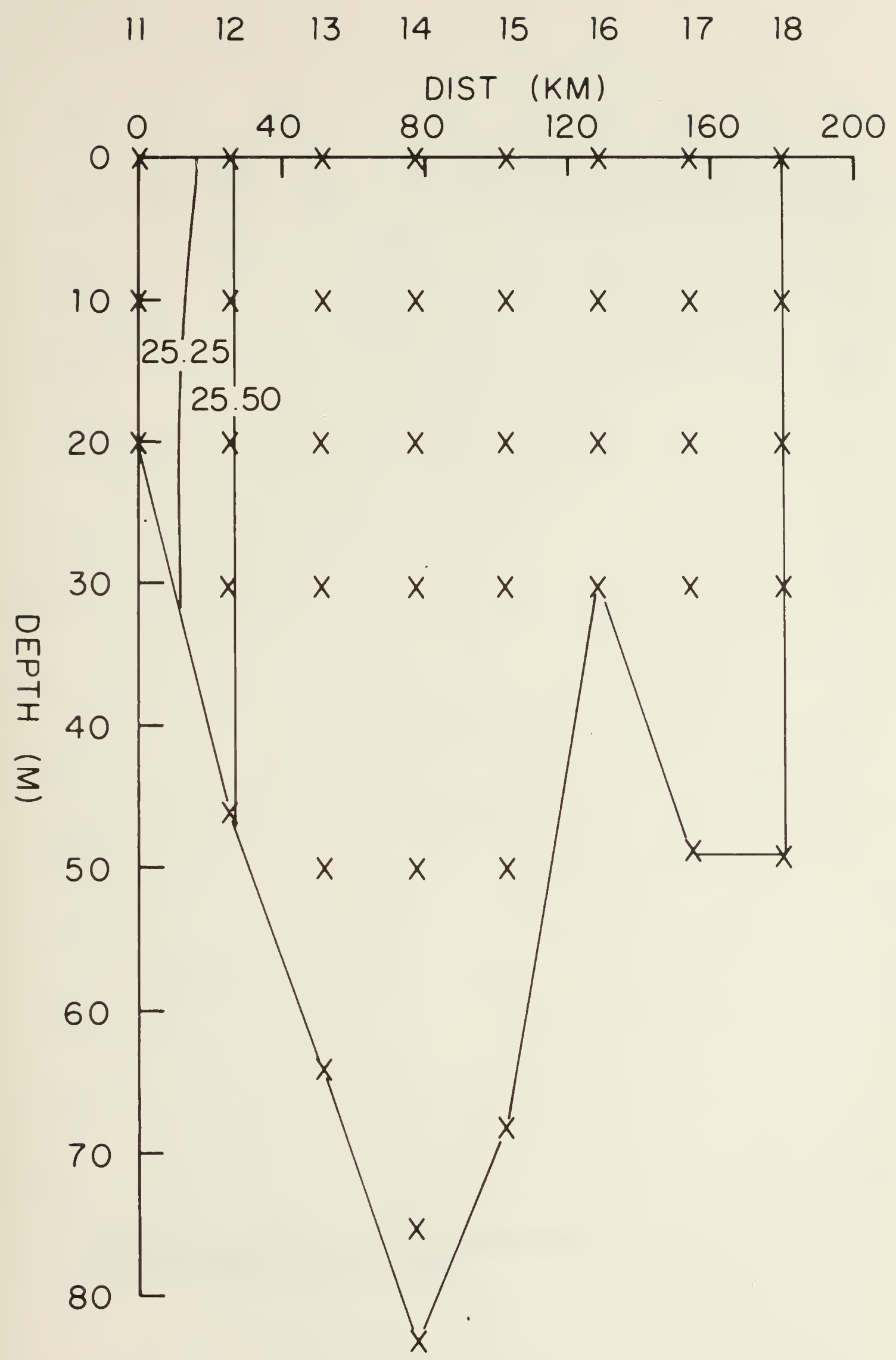

Figure 21. Density cross-section M7. MILLER FREEMAN, March 1970. 



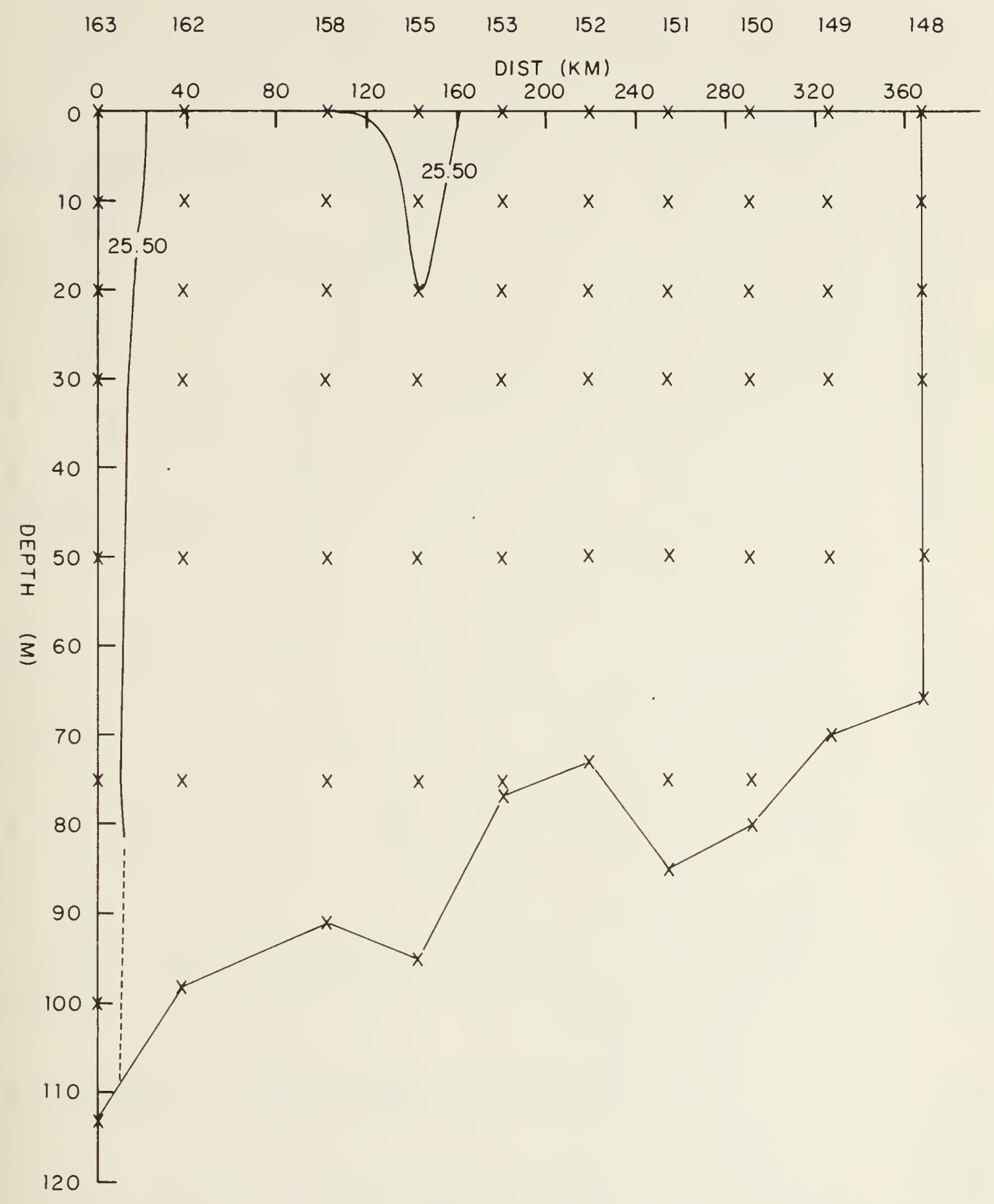

Figure 22. Density cross-section Al6. M/V PERVENETS, April 1964 . 



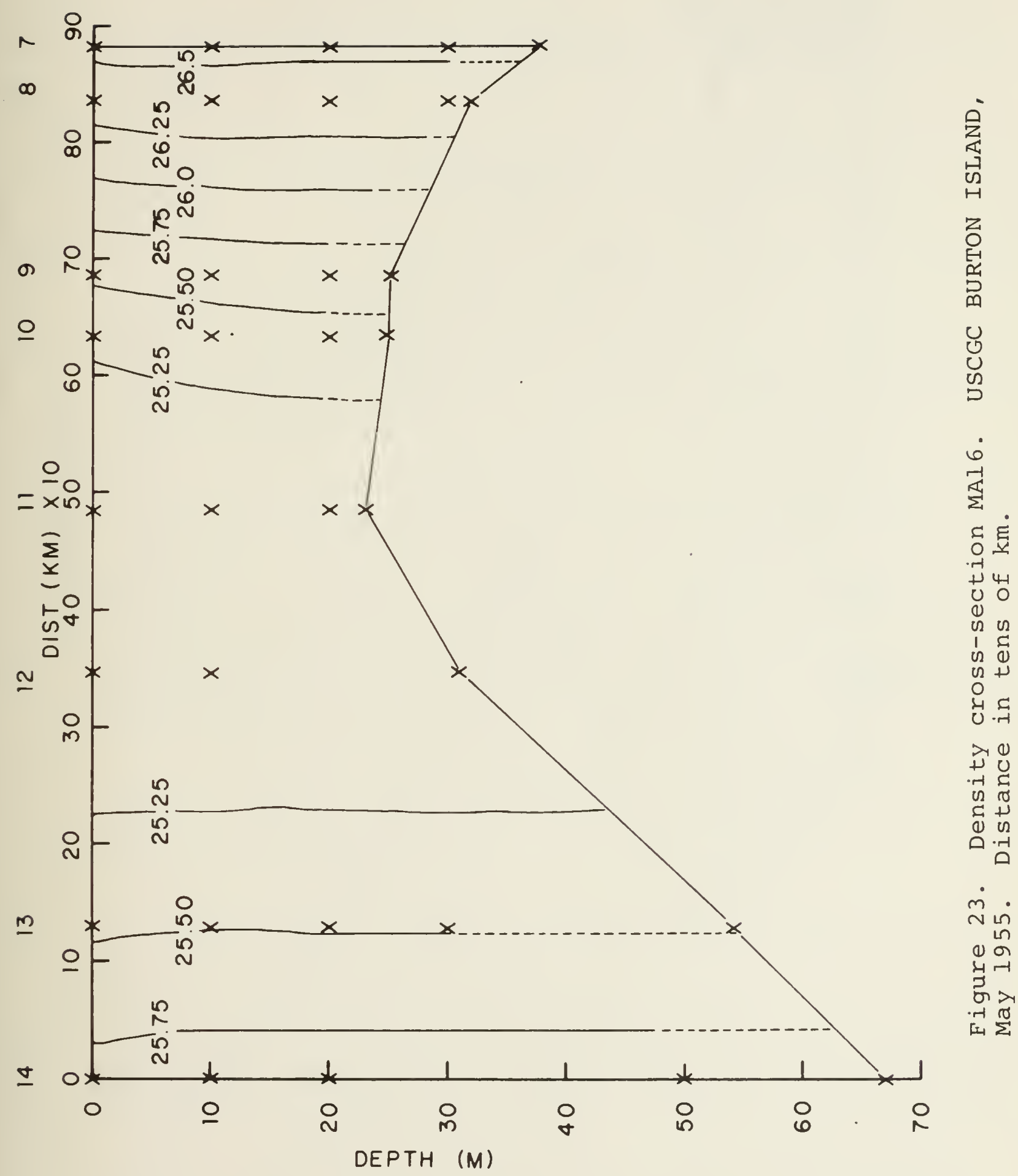





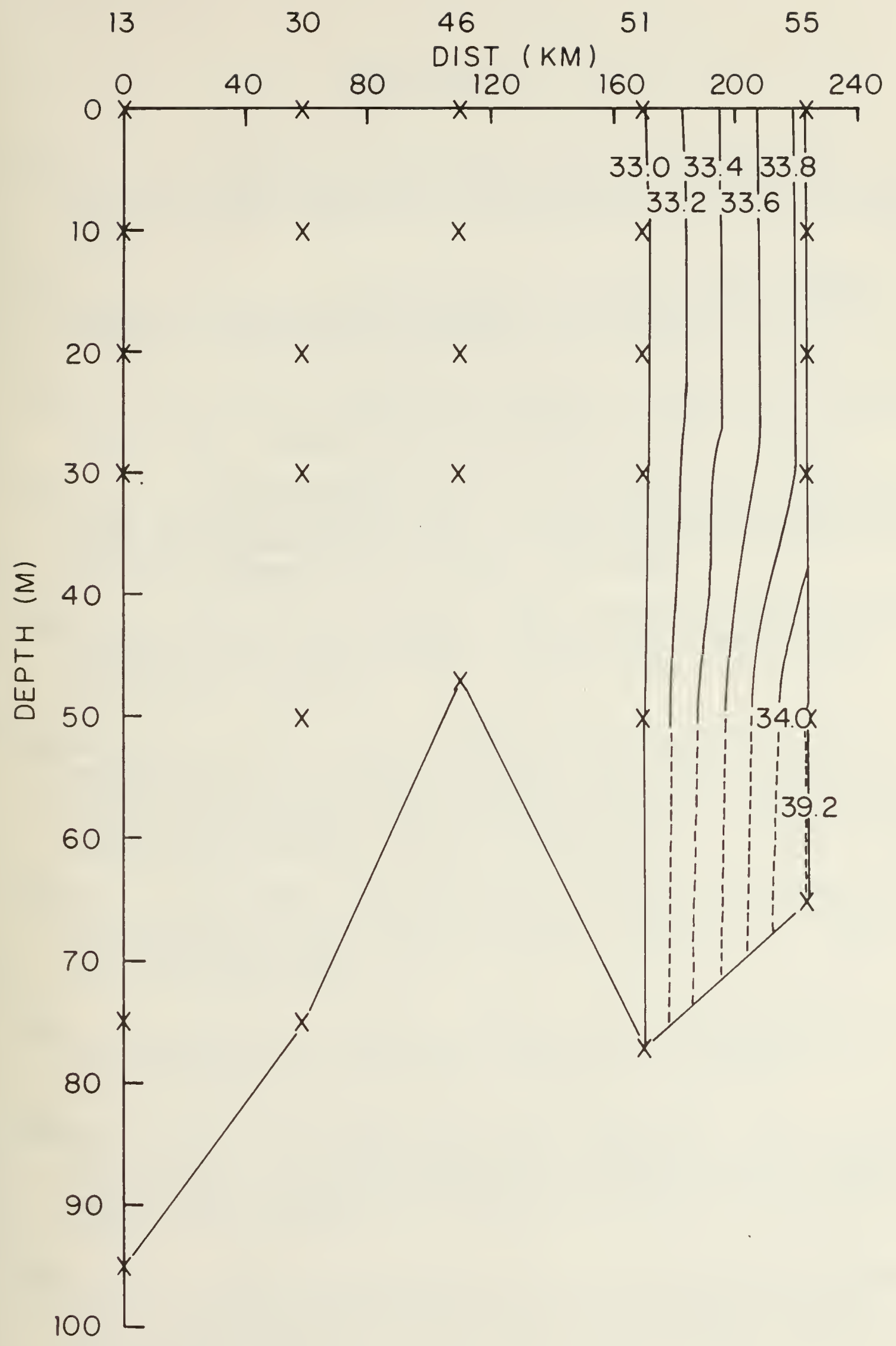

Figure 24. Salinity cross-section F6. USCGC NORTHWIND, February 1968. 



\section{BIBL IOGRAPHY}

Barnes, C. A., and T. G. Thompson, 1938, "Physical and Chemical Investigations in Bering Sea and Portions of the North Pacific Ocean," University Washington Publ. Oceanog., $3(2)$.

Coachman, L. K., K. Aagaard and R. B. Tripp, 1975, Bering Strait: The Regional Physical Oceanography, University of Washington Press, Seattle.

Dobrovol'skii, A. J., and V. S. Arsen'ev, 1959, "On the Question of the Currents of the Bering Sea" (in Russian), Problemy Severa (3), (Transl., Nat. Res. Coun. Can., Ottawa).

Fay, F. H., 1974, "The Role of Ice in the Ecology of Marine Mammals in the Bering Sea,". In Oceanography of the Bering Sea, Occasional Publication No. 2, Institute of Marine Science, University of Alaska, Fairbanks.

Garrison, G. R., and P. Becker, 1975, "Marginal Sea Ice Zone Oceanographic Measurements: Bering and Chukchi Seas; 1973 and 1974," APL-UW 7505, Applied Phys. Lab., Univ. of Washington, Seattle.

Gershanovich, D. E., N. C. Fadeev, T. G. Liubimova, P. A. Moiseev and V. V. Natarov, 1974, "Principal Results of Soviet Oceanographic Investigations in the Bering Sea," In Oceanography of the Bering Sea, Occasional Publication No. 2, Institute of Marine Science, University of Alaska, Fairbanks.

Graham, G. P., 1978, "Finestructure, Fronts and Currents in the Pacific Marginal Sea-Ice Zone - MIZPAC 77," Masters Thesis, Naval Postgraduate School, Monterey, CA, Tech. Rpt. NPS 68-78-006.

Hood, D. W. and E. J. Kelley, 1974., ed., Oceanography of the Bering Sea, Occasional Report No. 2, Institute of Marine Science, University of Alaska, Fairbanks.

Hughes, F. W., L. K. Coachman, and K. Aagaard, 1974, Circulation, "Transport and Water Exchange in the Western Bering Sea," In Oceanography of the Bering Sea, Occasional Report No. 2, Institute of Marine Science, University of Alaska, Fairbanks.

Husby, D. M. and G. L. Hufford, 1969, "Oceanographic Investigation of the Northern Bering Sea and Bering Strait," 8-21 June 1969, U.S. Coast Guard Oceanographic Report No. 42 , CG $373-42$. 

Kitano, K., 1970, "A Note on the Thermal Structure of the Eastern Bering Sea," J. Geophys Res. 75 (6), 1110-1115.

Koto, H. and Maeda, T., "On The Movement of Fish Shoals And The Change of Bottom Temperature on The Trawl-Fishing Ground of The Eastern Bering Sea" (in Japanese), Bull. Jap. Soc. Scient. Fish. 31 (4), 263-268.

Lafond, E. C. and D. W. Pritchard, 1952, "Physical Oceanographic Investigations in The Eastern Bering And Chukchi Seas During The Summer of 1947," J. Mar. Res. 11 (1), 69-86.

Lisitsyn, A. P., 1966, "Recent Sedimentation in the Bering Sea" (in Russian), Inst. Okeanol. Akad. Nauk S.S.S.R. (Transl. by Israel Program for Scientific Translations), U.S. Dept. of Commerce, Clearinghouse for Fed. Sci. and Techn. Info., 1969, 614 pp).

McRoy, C. P. and J. J. Goering, 1974, "The Influence of Ice on the Primary Productivity of the Bering Sea," In Oceanography of The Bering Sea, Occasional Report No. 2, Institute of Marine Science, University of Alaska, Fairbanks.

Natarov, V. V., 1963, "Water Masses and Currents of the Bering Sea" (in Russian), Trudy VNIRO 48 (Transl. 1968, in Soviet Fisheries Investigations in the Northeastern Pacific, Part 2).

Paquette, R. G. and R. H. Bourke, 1978, "Temperature Fronts in the Marginal Sea-Ice Zone of the Chukchi Sea," Paper presented at the Fall Annual Meeting, American Geophysical Union, San Francisco, Abstract in EOS, Trans. Am. Geophys. Union, 59(12).

Paquette, R. G. and R. H. Bourke, 1979, "Temperature Finestructure Near the Sea-Ice Margin of the Chukchi Sea," J. Geophys. Res. 84 (C3), 1155-1164.

U.S. Naval Oceanographic Office, 1958, Oceanographic Atlas of the Polar Seas, Part II, Arctic. H.O. Publ. No. 705. 

1. Director

Applied Physics Laboratory

University of Washington

1013 Northeast 40 th Street

Seattle, Washington 98195

$$
\begin{aligned}
& \text { Mr. Robert E. Francois } \\
& \text { Mr. E. A. Pence } \\
& \text { Mr. G. R. Garrison } \\
& \text { Library }
\end{aligned}
$$

2. Director

Arctic Submarine Laboratory

Code 54, Building 371

Naval Ocean Systems Center

San Diego, California 92152

3. Superintendent

Naval Postgraduate School

Monterey, California 93940

$$
\begin{aligned}
& \text { Library, Code } 0142 \\
& \text { Dr. R. G. Paquette Code } 68 \mathrm{~Pa} \\
& \text { Dr. R. H. Bourke Code } 68 \mathrm{Bf}
\end{aligned}
$$

4. Polar Research Laboratory, Inc.

123 Santa Barbara Street

Santa Barbara, California 93101

5. Chief of Naval Operations

Department of the Navy

Washington, D. C. 20350

$$
\begin{aligned}
& \text { NOP-02 } \\
& \text { NOP-22 } \\
& \text { NOP-946D2 } \\
& \text { NOP-095 } \\
& \text { NOP-098 }
\end{aligned}
$$

6. Commander

Submarine Squadron THREE

Fleet Post Office

San Diego, California 92132

7. Commander

Submarine Group FIVE

Fleet Post Office

San Diego, California 92132 

8. Director

Marine Physical Laboratory

Scripps Institution of Oceanography

San Diego, California 92132

9. Commanding Officer

Naval Intelligence Support Center

4301 Suitland Road

Washington, D. C. 20390

10. Commander

Naval Electronic Systems Command

Naval Electronic Systems Command Headquarters

Department of the Navy

Washington, D. C. 20360

NESC 03

PME 124

11. Director

Woods Hole Oceanographic Institution

Woods Hole, Massachusetts 02543

12. Commanding Officer

Naval Coastal Systems Laboratory

Panama City, Florida 32401

13. Commanding Officer

Naval Submarine School

Box 700, Naval Submarine Base, New London

Groton, Connecticut 06340

14. Assistant Secretary of the Navy

(Research and Development)

Department of the Navy

Washington, D. C. 20350

15. Director of Defense Research and Engineering I Office of Assistant Director (Ocean Control)

The Pentagon

Washington, D. C. 20301

16. Commander, Naval Sea Systems Command

Naval Sea Systems Command Headquarters

Department of the Navy

Washington, D. C. 20362

17. Chief of Naval Research

Department of the Navy

800 North Quincy Street

Arlington, Virginia 22217

Code 102-OS

Code 220

Code 461 

18. Project Manager

Anti-Submarine Warfare Systems Project Office (PM4)

Department of the Navy

Washington, D. C. 20360

19. Commanding officer

Naval Underwater Systems Center

Newport, Rhode Island 02840

20. Commander

Naval Air Systems Command

Headquarters

Department of the Navy

Washington, D. C. 20361

21. Commander

Naval Oceanographic Office

Washington, D. C. 20373

Attention: Library Code 3330

22. Director

Defense Supply Agency

Defense Documentation Center

Cameron Station

Alexandria, Virginia 22314

23. Director

Advanced Research Project Agency

1400 Wilson Boulevard

Arlington, Virginia 22209

24. Commander SECOND Fleet

Fleet Post Office

New York, New York 09501

25. Commander THIRD Fleet

Fleet Post Office

San Francisco, California 96601

26. Commander

Naval Surface Weapons Center

White Oak

Silver Spring, Maryland 20910

Mr. M. M. Kleinerman

Library

27. Officer-in-Charge

New London Laboratory

Naval Underwater Systems Center

New London, Connecticut 06320 

28. Commander

Submarine Development Group TWO

Box 70

Naval Submarine Base

New London

Groton, Connecticut 06340

29. Commander

Naval Weapons Center

China Lake, California 93555

Attention: Library

30. Commander

Naval Electronics Laboratory Center

271 Catalina Boulevard

San Diego, California 92152

Attention: Library

31. Director

Naval Research Laboratory

Washington, D. C. 20375

Attention: Technical Information Division

32. Director

Ordnance Research Laboratory

Pennsylvania State University

State College, Pennsylvania 16801

33. Commander Submarine Force

U. S. Atlantic Fleet

Norfolk, Virginia 23511

34. Commander Submarine Force

U. S. Pacific Fleet

$\mathrm{N}-21$

Pearl Harbor, Hawaii 96860

Commander

Naval Air Development Center

Warminster, Pennsylvania 18974

36. Commander

Naval Ship Research and Development Center

Bethesda, Maryland 20084

37. Chief of Naval Material

Department of the Navy

Washington, D. C. 20360

NMAT 03

NMAT 034

NMAT 0345 

38. Commandant

U. S. Coast Guard Headquarters

400 Seventh Street, S.W.

Washington, D. C. 20590

39. Commander

Pacific Area, U. S. Coast Guard

630 Sansome Street

San Francisco, California 94126

40. Commander

Atlantic Area, U. S. Coast Guard

Governors Island

New York, New York 10004

41. Commanding Officer

U. S. Coast Guard Oceanographic Unit

Building 159E, Navy Yard Annex

Washington, D. C. 20590

Dr. D. G. Mountain

42. Department of Oceanography, Code 68

Naval Postgraduate School

Monterey, California 93940

43. Oceanographer of the Navy

Naval Oceanography Div (OP 952)

Navy Department

washington, DC 20350

44. Office of Naval Research, Code 410

NORDA, NSTL

Bay St. Louis-Mississippi 39520

45. Dr. Robert E. Stevenson

Scientific Liaison Office, ONR

Scripps Institution of Oceanography

La Jolla, California 92037

46. SIO Library

University of California, San Diego

P. O. Box 2367

La Jolla, California 92037

47. University of Washington

Seattle, Washington 98105

Dept. of Oceanography Library

Dr. L. K. Coachman

48. Department of Oceanorraphy Library

Oregon State University

Corvallis, Oregon 97331 

49. Commanding Officer

Fleet Numerical Weather Central

Monterey, California 93940

50. Commanding officer

Naval Environmental Prediction Research

Facility

Monterey, California 93940

51. Director

Naval Arctic Research Laboratory

Barrow, Alaska 99723

Library

52. Department of the Navy

Commander Oceanographic System Pacific

Box 1390

FPO San.Francisco 96610

53. Commander

Naval Oceanography Command

National Space Technology Laboratories

Bay St. Louis, Mississippi 39529

54. NORDA

Technical Director

Bay St. Louis, Mississippi 39520

55. Department of Meteorology Library

Naval Postgraduate School, Code 63

Monterey, California 93940

56. LCDR Gordon P. Graham

Canadian Forces Fleet School

Halifax, Nova Scotia

Canada, B3K 2 XO

57. Commanding officer

Naval Facility

Lewes, Delaware 19958

58. John L. Newton

Science Applications, Inc.

1200 Prospect Street

P.O. Box 2351

La Jolla, CA 92038

59. LT Walter P. Lohrmann

USS SHREVEPORT (LPD-12)

Fleet Post Office

New York, New York 09501 





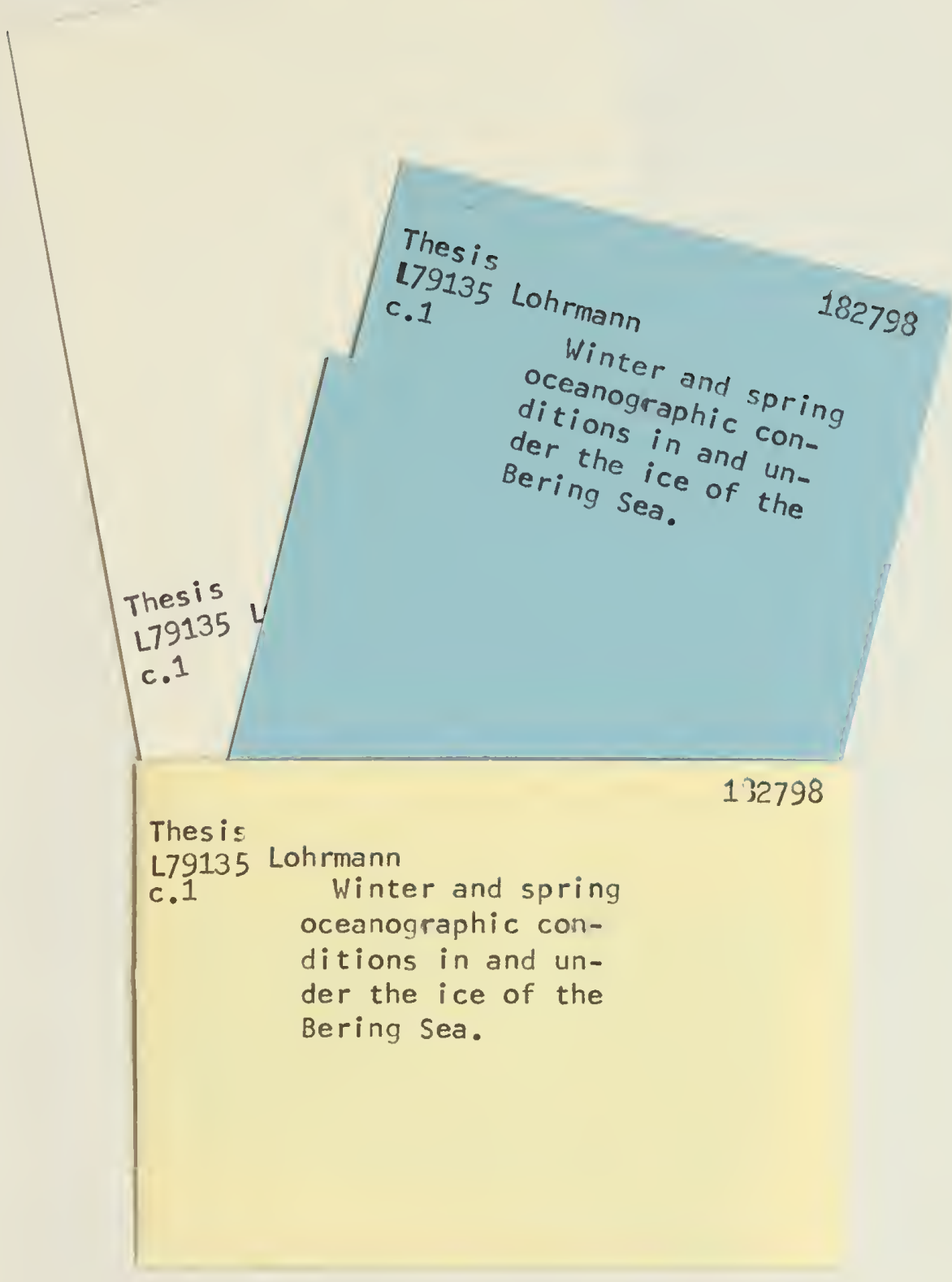




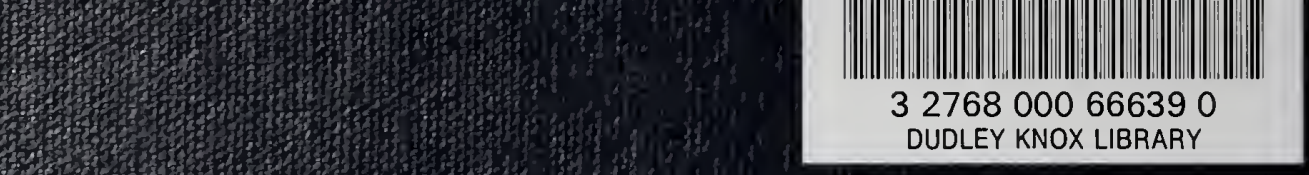

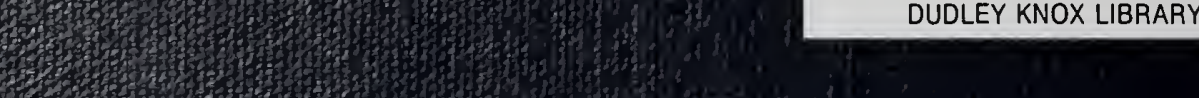
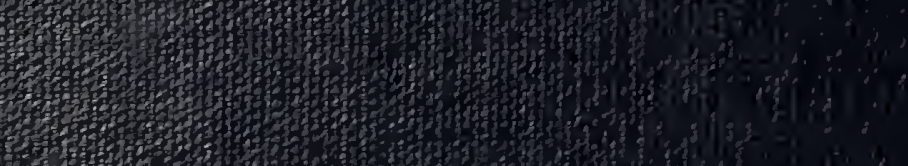

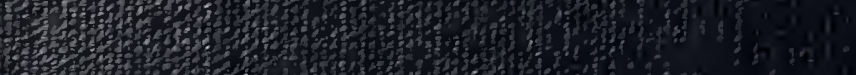
Hof

6

\section{(3)}

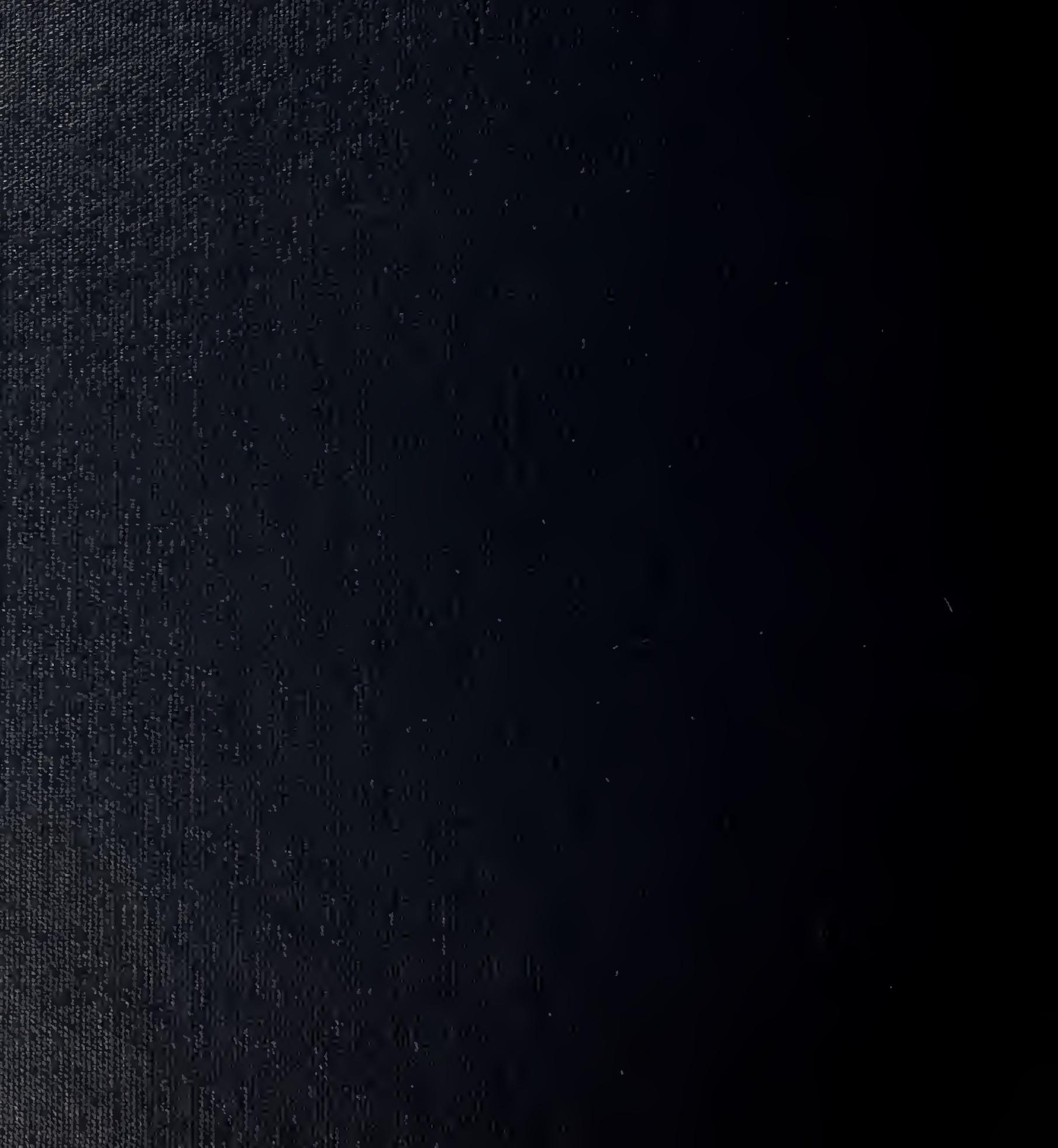

